\title{
Global Impact of COVID-19 on Stroke Care and IV Thrombolysis
}

Raul G. Nogueira, MD, Muhammad M. Qureshi, MBBS, MPH, Mohamad Abdalkader, MD, Sheila Ouriques Martins, MD, PhD, Hiroshi Yamagami, MD, PhD, Zhongming Qiu, MD, PhD, Ossama Yassin Mansour, MD, PhD, Anvitha Sathya, Anna Czlonkowska, MD, PhD, Georgios Tsivgoulis, MD, PhD, Diana Aguiar de Sousa, MD, Jelle Demeestere, MD, Robert Mikulik, MD, PhD, Peter Vanacker, MD, PhD, James E. Siegler, MD, Janika Kõrv, MD, PhD, Jose Biller, MD, Conrad W. Liang, MD, PhD, Navdeep S. Sangha, MD, Alicia M. Zha, MD, Alexandra L. Czap, MD, Christine Anne Holmstedt, MD, Tanya N. Turan, MD, George Ntaios, MD, Konark Malhotra, MD, Ashis Tayal, MD, Aaron Loochtan, DO, Annamarei Ranta, MD, PhD, Eva A. Mistry, MBBS, Anne W. Alexandrov, PhD, David Y. Huang, MD, PhD, Shadi Yaghi, MD, Eytan Raz, MD, PhD, Sunil A. Sheth, MD, Mahmoud H. Mohammaden, MD, Michael Frankel, MD, Eric Guemekane Bila Lamou, MD, MSc, Hany M. Aref, MD, Ahmed Elbassiouny, MD, Farouk Hassan, MD, Tarek Menecie, MD, Wessam Mustafa, MD, Hossam M. Shokri, MD, Tamer Roushdy, MD, Fred S. Sarfo, MD, Tolulope Oyetunde Alabi, MBBS, MWACP, Babawale Arabambi, MBBS, FWACP, Ernest O. Nwazor, MBBS, FMCP, Taofiki Ajao Sunmonu, MD, Kolawole Wahab, MBBS, MPH, MSc, FMCP, Joseph Yaria, MBBS, MSc, Haytham Hussein Mohammed, MD, Philip B. Adebayo, MBBS, MSc, FWACP, FCP, Anis D. Riahi, MD, Samia Ben Sassi, MD, et al. on behalf of the SVIN COVID19 Global Stroke Registry

Neurology ${ }^{\circledR}$ 2021;96:e2824-e2838. doi:10.1212/WNL.0000000000011885

\section{Abstract}

\section{Objective}

To measure the global impact of COVID-19 pandemic on volumes of IV thrombolysis (IVT), IVT transfers, and stroke hospitalizations over 4 months at the height of the pandemic (March 1 to June 30, 2020) compared with 2 control 4-month periods.

\section{Methods}

We conducted a cross-sectional, observational, retrospective study across 6 continents, 70 countries, and 457 stroke centers. Diagnoses were identified by their ICD-10 codes or classifications in stroke databases.

\section{Results}

There were 91,373 stroke admissions in the 4 months immediately before compared to 80,894 admissions during the pandemic months, representing an $11.5 \%$ (95\% confidence interval [CI] -11.7 to $-11.3, p<0.0001)$ decline. There were 13,334 IVT therapies in the 4 months preceding compared to 11,570 procedures during the pandemic, representing a $13.2 \%$ (95\% CI -13.8 to $-12.7, p<0.0001)$ drop. Interfacility IVT transfers decreased from 1,337 to 1,178 , or an $11.9 \%$ decrease $(95 \% \mathrm{CI}-13.7$ to $-10.3, p=0.001)$. Recovery of stroke hospitalization volume (9.5\%, 95\% CI 9.2-9.8, $p<0.0001$ ) was noted over the 2 later (May, June) vs the 2 earlier (March, April) pandemic months. There was a $1.48 \%$ stroke rate across 119,967 COVID-19 hospitalizations. Severe acute respiratory syndrome coronavirus 2 (SARS-CoV-2) infection was noted in 3.3\% $(1,722 / 52,026)$ of all stroke admissions.

\section{Conclusions}

The COVID-19 pandemic was associated with a global decline in the volume of stroke hospitalizations, IVT, and interfacility IVT transfers. Primary stroke centers and centers with higher COVID-19 inpatient volumes experienced steeper declines. Recovery of stroke hospitalization was noted in the later pandemic months.

\author{
Correspondence \\ Dr. Nguyen \\ thanh.nguyen@bmc.org
}

\section{RELATED ARTICLE}

Editorial

Where in the World Have All the Strokes Gone?

Page 1069

\section{MORE ONLINE}

COVID-19 Resources For the latest articles, invited commentaries, and blogs from physicians around the world NPub.org/COVID19 


\section{Glossary}

$\mathbf{C I}=$ confidence interval;, $\mathbf{C O V I D}-\mathbf{1 9}=$ coronavirus disease 2019;, $\mathbf{C S C}=$ comprehensive stroke center;, $\mathbf{I C D}-\mathbf{1 0}=$ International Classification of Diseases-10; , IQR = interquartile range; , IVT = IV thrombolysis; , PSC = primary stroke center; , SARS-CoV-2 = severe acute respiratory syndrome coronavirus 2.

The coronavirus disease 2019 (COVID-19) pandemic has restructured health care systems worldwide to care for critically ill patients with COVID-19. ${ }^{1}$ The high virulence of severe acute respiratory syndrome coronavirus 2 (SARS-CoV-2) and COVID-19-related morbidity and mortality have strained paradigms of health care worldwide. Several neurologic manifestations have been reported in association with SARS-CoV-2, including ischemic, hemorrhagic, and cerebral venous stroke. Whereas infection can trigger an inflammatory prothrombotic cascade and ischemic stroke, stroke can induce immune dysregulation and expose a patient's vulnerability to infection. ${ }^{2}$ The heterogeneity of stroke subtypes that have emerged in association with SARS-CoV-2 $2^{3,4}$ suggests heterogeneous mechanisms of stroke including endothelial dysfunction, thrombotic diathesis, and nonspecific effects of inflammation. ${ }^{5}$ Patients with COVID-19-associated stroke have been reported to have a higher risk for severe disability and mortality. ${ }^{4,6,7}$

Whereas there has been an increase in thromboembolic events reported with COVID- $19,{ }^{8}$ a decline in acute stroke code activations, stroke hospitalizations, and mechanical thrombectomy volumes have been reported at local, regional, and national levels, ${ }^{9-13}$ with most reports from comprehensive stroke centers (CSCs) in highly resourced countries. There is a relative paucity of information on the effect of the pandemic on acute stroke hospitalization volume and IV thrombolysis (IVT) acute treatment in low- or middle-income countries and in primary stroke centers (PSCs) without endovascular capability. There is also little information on the recovery of volumes in the later phases of the pandemic.

\section{Objectives and Prespecified Hypothesis}

In this context, the present study aims to broaden the scope of evaluating the effect of the COVID-19 pandemic on global stroke care to include developed and developing nations in the early and later phases of the COVID-19 pandemic. Our primary aim was to evaluate the effect of COVID-19 on stroke care as measured by the changes in volumes for (1) overall stroke hospitalizations and (2) IVT treatment (both direct presenting and patients transferred with IVT) for acute stroke across the prepandemic and pandemic periods in a multinational pool of PSCs and CSCs. In a secondary aim, the pandemic months were divided into an early (March 1, 2020, to April 30, 2020) and later phase (May 1, 2020, to June 30, 2020) to evaluate for stroke or IVT volume recovery in the later months.

We hypothesized that, in the face of the pandemic's strain on health care infrastructure, (1) a global reduction in all 3 aforementioned measurements of stroke care would occur over the pandemic in relation to both prepandemic periods, (2) hospitals with higher COVID-19 inpatient volumes would report greater decreases in stroke admissions and IVT volumes (direct and transfers) compared to hospitals with lower COVID-19 inpatient volumes, (3) the degree of decline in stroke hospitalizations and IVT volumes would be less profound in CSC compared to PSC, (4) a geographic variation would exist in the intensity of decline in stroke care, and (5) a recovery in stroke hospitalizations and IVT volumes would be observed in the 2 later pandemic months vs the early pandemic period.

\section{Methods}

\section{Study Design}

This was a cross-sectional, observational, retrospective study evaluating monthly volumes of consecutive patients hospitalized with a diagnosis of COVID-19, stroke, IVT treatment, and IVT transfers. The diagnoses were identified by their related ICD-10 codes (primary, secondary, or tertiary discharge codes) or classifications in clinical stroke databases maintained at participating centers. Case ascertainment was verified by a physician or stroke coordinator.

\section{Setting and Participants}

Data were collected from collaborators of the Society of Vascular and Interventional Neurology (SVIN) including the Latin America Stroke Group, Middle East North Africa Stroke and Interventional Neurotherapies Organization (MENA-SINO), the Japanese Society of Vascular \& Interventional Neurology Society (JSVIN), and academic partners from 6 continents, 70 countries, and 457 centers. Centers were screened for potential external confounders that could explain any unexpected changes in volumes. Of the 457 centers, 54 centers were excluded due to incomplete data or confounders. One center in Africa (Zimbabwe) was excluded due to a health care worker strike from September to January. One center in Egypt was excluded due to the emergency department being closed most days in June 2020. One center in Arkansas was excluded from the stroke hospitalization volume analysis because this center became the designated center for all patients with stroke in its region during the pandemic, resulting in an abrupt increase in stroke volumes. One center in Malaysia was excluded as this was a new center in May 2020. Of the remaining 403 hospitals, 285 centers contributed to both stroke and thrombolysis volume data. For IVT transfers, centers with a mean of 4 or more transfers per month during the baseline control period were included. 
We compared the stroke, IVT, and IVT transfer diagnosis in the 4 initial months of the pandemic (March 1, 2020, to June 30,2020 ) with (1) the immediately preceding 4 months (November 2019 to February 2020) as the primary analysis and (2) the equivalent 4 months in the previous year (March $1,2019$, to June 30,2019$)$ as the secondary analysis. The primary analysis provided a picture of stroke care utilization prior to COVID-19, whereas the secondary analysis allowed for the adjustment for seasonal variations in the risks for stroke. $^{14}$

\section{Study Variables and Outcomes Measures}

Stroke hospitalization was defined as admission to a hospital with a TIA, ischemic stroke, or intracerebral hemorrhage. IVT was defined as acute ischemic stroke treatment with IVT. IVT transfer was defined as a patient who was treated with IVT and transferred to another stroke center. Centers were asked not to duplicate patients receiving IVT if both referral and recipient centers were included in this analysis; the patient was computed with the referring center, and as an IVT transfer for the recipient hospital. COVID-19 hospitalization was defined as any patient admitted with COVID19 diagnosis to the hospital, which could encompass nonneurologic diagnosis.

Median monthly volumes for overall stroke hospitalizations and IVT treatments for direct presenting and transfer patients were computed and compared across the pandemic and prepandemic periods for the overall population and across the low, intermediate, and high volume strata based on mean monthly volume tertiles for COVID-19 hospitalizations $(\leq 6.2$ vs $>6.2$ to 61.9 vs $>61.9$ COVID-19 admissions/month), stroke admissions ( $\leq 39.0$ vs $>39.0$ to 72.9 vs $>72.9$ stroke admissions/month), and IVT volume ( $\leq 4.0$ vs $>4.0$ to 10.0 vs $>10.0 \mathrm{IVT} /$ month).

\section{Standard Protocol Approvals, Registrations, and Patient Consents}

This was an investigator-initiated project. The first and last authors wrote the first draft of the manuscript with subsequent input of all coauthors. There were no external funding sources. The institutional review boards from the coordinating sites (Emory University School of Medicine and Boston University School of Medicine) considered that the investigators did not have access to identifiable protected health information and thus no informed consent or institutional review board oversight was required since the study did not meet the federal description of human subject research.

\section{Data Availability}

The authors declare that all supporting data are available within the article. Supplemental data are available from Dryad (tables e-1 to e-6, figure e-1, e-2, doi.org/10.5061/dryad. gljwstqpw). Anonymized data are available upon reasonable request.

\section{Statistics}

The monthly volumes for IVT and stroke hospitalizations were compared for the period before ( 1 year and immediately before) and during the COVID-19 pandemic. The normality of the data was tested with the Shapiro-Wilk test. The nonparametric Wilcoxon signed-rank test was applied to compare differences in monthly volume between 2 time periods. The analyses were repeated in the setting of low, intermediate, and high COVID-19 and stroke volume hospitals.

Figure 1 Monthly Stroke vs Coronavirus Disease 2019 (COVID-19) Admissions

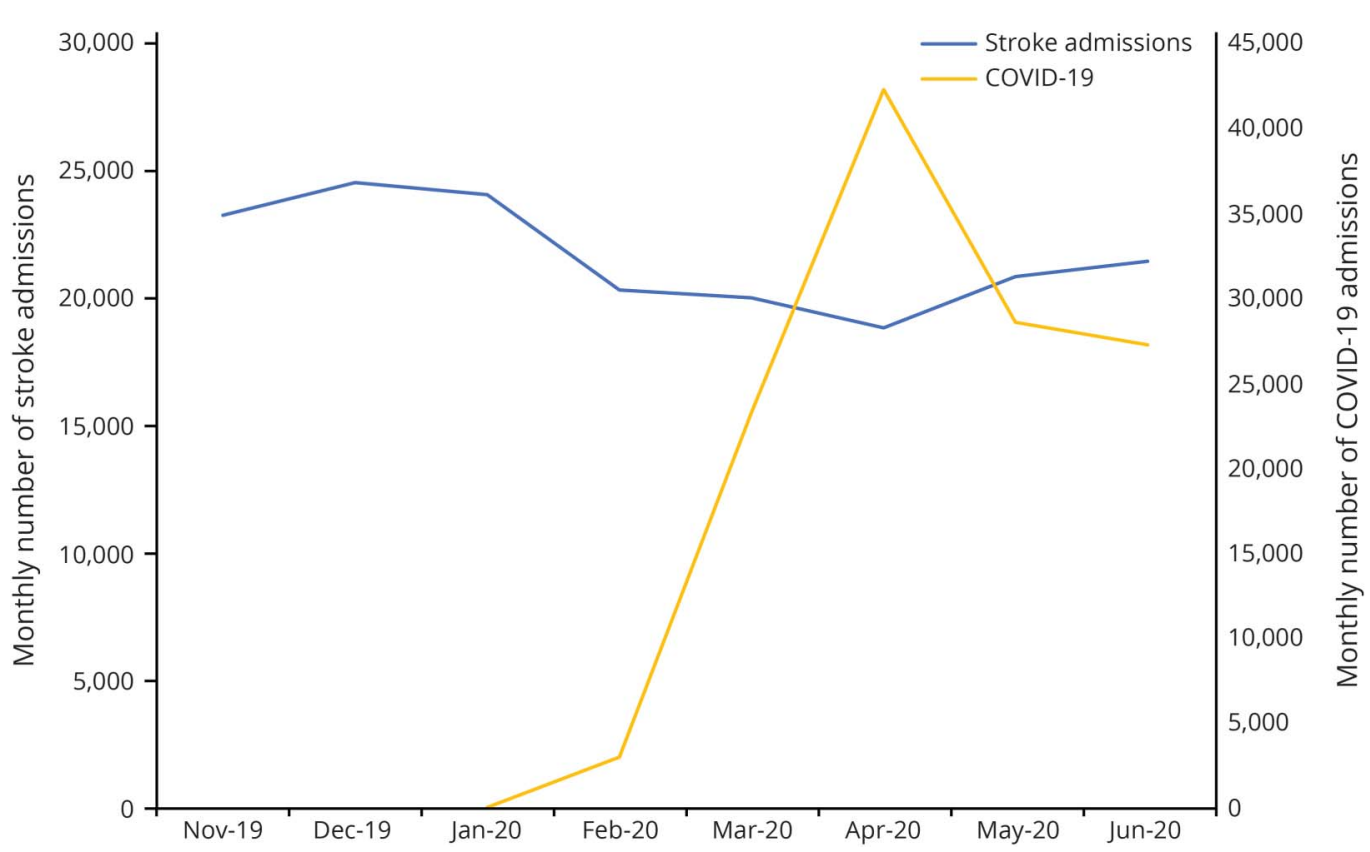


We looked at the percentage change in the number of IV thrombolysis and stroke admissions before and during the COVID-19 pandemic. The 95\% confidence intervals (CIs) for percentage change were calculated using the Wilson procedure without correction for continuity. The relative percentage decrease in volume between low, intermediate, and high-volume hospitals was tested using the $z$ test of proportion. All data were analyzed using SAS version 9.4 (SAS Institute) and the significance level was set at a $p$ value of $<0.05$.

\section{Results}

There were $82,465,91,373$, and 80,894 stroke hospitalizations (overall $\mathrm{n}=254,732$ ) and 12,527, 13,334 and 11,570 IVT therapies (overall $\mathrm{n}=37,431$ ) included across the 4-month prior-year pandemic, 4-month immediately prepandemic, and 4-month pandemic periods, respectively. Country-specific data contributions and relative changes across the pandemic are summarized in table e-3 (doi.org/10.5061/dryad. gljwstqpw).

\section{Stroke Hospitalization}

Monthly stroke hospitalization as compared with COVID-19 hospitalization volumes are represented in figure 1 . In the primary analysis, there were 91,373 hospitalizations in the 4 months of the prepandemic period compared to 80,894 during the pandemic months, representing an $11.5 \%$ drop (95\% CI -11.7 to $-11.3, p<0.0001$; monthly median [interquartile range (IQR)] stroke hospitalization volume/ center 54.0 [30.8-86.5] to 43.0 [24.3-71.3], $p<0.0001, \mathrm{n}=$ 325 sites) (table 1). There was geographic variation of the decline in stroke hospitalization: Asia, $-6.5 \%$ (95\% CI -6.8 to -6.3, $\mathrm{p}<0.0001$ ); North America, $-18.8 \%$ (95\% CI -19.3 to $-18.3, p<0.0001)$; Europe, $-10.9 \%$ (95\% CI -11.3 to -10.5 ,

Table 1 Stroke Volumes Immediately Before and During the Coronavirus Disease 2019 (COVID-19) Pandemic

\begin{tabular}{|c|c|c|c|c|c|c|c|c|c|c|}
\hline & \multicolumn{5}{|c|}{ Overall volume } & \multicolumn{5}{|c|}{ Monthly volume, median (IQR) } \\
\hline & $\mathbf{N}$ & n1 & $\mathrm{n} 2$ & $\begin{array}{l}\text { Relative (\%) } \\
\text { change, \% (95\% } \\
\text { CI) }\end{array}$ & $p$ Value & $\mathbf{N}$ & $\begin{array}{l}\text { Immediately } \\
\text { before }\end{array}$ & $\begin{array}{l}\text { During } \\
\text { COVID-19 }\end{array}$ & $\begin{array}{l}\text { Difference }{ }^{a} \\
(95 \% \mathrm{Cl})\end{array}$ & $p$ Value \\
\hline Overall & 325 & 91,373 & 80,894 & $\begin{array}{l}-11.5(-11.7 \text { to } \\
-11.3)\end{array}$ & $<0.0001$ & 325 & $\begin{array}{l}54.0 \\
(30.8-86.5)\end{array}$ & $\begin{array}{l}43.0 \\
(24.3-71.3)\end{array}$ & $\begin{array}{l}-6.7(-8.3 \text { to } \\
-5.8)\end{array}$ & $<0.0001$ \\
\hline \multicolumn{11}{|l|}{$\begin{array}{l}\text { Hospital COVID-19 } \\
\text { volume }^{\text {b }}\end{array}$} \\
\hline Low & 85 & 29,835 & 28,890 & $-3.2(-3.4$ to -3.0$)$ & $<0.0001$ & 85 & $\begin{array}{l}51.5 \\
(24.5-89.8)\end{array}$ & $\begin{array}{l}46.3 \\
(21.5-86.3)\end{array}$ & $\begin{array}{l}-3.0(-5.0 \text { to } \\
1.5)\end{array}$ & 0.002 \\
\hline Intermediate & 102 & 24,849 & 21,879 & $\begin{array}{l}-12.0(-12.4 \text { to } \\
-11.6)\end{array}$ & $<0.0001$ & 102 & $\begin{array}{l}50.2 \\
(27.8-83.0)\end{array}$ & $\begin{array}{l}38.8 \\
(24.5-68.0)\end{array}$ & $\begin{array}{l}-7.5(-9.0 \text { to } \\
-4.0)\end{array}$ & $<0.0001$ \\
\hline High & 91 & 26,575 & 21,913 & $\begin{array}{l}-17.5(-18.0 \text { to } \\
-17.1)\end{array}$ & $<0.0001$ & 91 & $\begin{array}{l}61.3 \\
(48.5-96.3)\end{array}$ & $\begin{array}{l}49.0 \\
(35.8-71.3)\end{array}$ & $\begin{array}{l}-11.3(-13.8 \\
\text { to }-8.0)\end{array}$ & $<0.0001$ \\
\hline \multicolumn{11}{|l|}{$\begin{array}{l}\text { Hospital stroke } \\
\text { volume }\end{array}$} \\
\hline Low & 113 & 10,518 & 8,951 & $\begin{array}{l}-14.9(-15.6 \text { to } \\
-14.2)\end{array}$ & $<0.0001$ & 113 & $\begin{array}{l}23.5 \\
(16.5-31.0)\end{array}$ & $\begin{array}{l}20.3 \\
(12.0-25.8)\end{array}$ & $\begin{array}{l}-3.2(-4.3 \text { to } \\
-2.0)\end{array}$ & $<0.0001$ \\
\hline Intermediate & 108 & 23,698 & 19,449 & $\begin{array}{l}-17.9(-18.4 \text { to } \\
-17.5)\end{array}$ & $<0.0001$ & 108 & $\begin{array}{l}55.1 \\
(48.0-61.3)\end{array}$ & $\begin{array}{l}43.3 \\
(37.6-52.4)\end{array}$ & $\begin{array}{l}-9.6(-11.0 \\
\text { to }-7.7)\end{array}$ & $<0.0001$ \\
\hline High & 104 & 57,157 & 52,494 & $-8.2(-8.4$ to -7.9$)$ & $<0.0001$ & 104 & $\begin{array}{l}105.2 \\
(87.9-146.3)\end{array}$ & $\begin{array}{l}94.7 \\
(72.4-145.3)\end{array}$ & $\begin{array}{l}-11.8(-16.0 \\
\text { to }-8.5)\end{array}$ & $<0.0001$ \\
\hline \multicolumn{11}{|l|}{$\begin{array}{l}\text { Primary vs } \\
\text { comprehensive } \\
\text { stroke center }^{\mathrm{d}}\end{array}$} \\
\hline Primary & 89 & 14,782 & 12,222 & $\begin{array}{l}-17.3(-17.9 \text { to } \\
-16.7)\end{array}$ & $<0.0001$ & 89 & $\begin{array}{l}31.5 \\
(19.8-52.0)\end{array}$ & $\begin{array}{l}26.0 \\
(13.3-42.0)\end{array}$ & $\begin{array}{l}-5.3(-8.0 \text { to } \\
4.0)\end{array}$ & $<0.0001$ \\
\hline Comprehensive & 236 & 76,591 & 68,672 & $\begin{array}{l}-10.3(-10.6 \text { to } \\
-10.1)\end{array}$ & $<0.0001$ & 236 & $\begin{array}{l}61.3 \text { (39.1 to } \\
95.9)\end{array}$ & $\begin{array}{l}51.4 \\
(30.4-85.7)\end{array}$ & $\begin{array}{l}-7.5(-9.2 \text { to } \\
-6.0)\end{array}$ & $<0.0001$ \\
\hline
\end{tabular}

Abbreviations: $\mathrm{Cl}$ = confidence interval; IQR = interquartile range; $\mathrm{N}=$ number of hospitals; $\mathrm{n}=$ number of admissions.

$\mathrm{n} 1$ and immediately before are based on 4 months before the pandemic (November 2019 to February 2020). n2 and during COVID-19 are based on March 2020 to June 2020. $p$ Values are from Poisson means test (overall volume analysis) and Wilcoxon signed-rank test (monthly volume analysis).

a Difference denotes the median difference between the 2 time periods.

${ }^{\mathrm{b}} \mathrm{p}$ : Low vs intermediate $<0.0001$; low vs high $<0.0001$; intermediate vs high $<0.0001$.

c $p$ : Low vs intermediate $<0.0001$; low vs high $<0.0001$; intermediate vs high $<0.0001$.

${ }^{\mathrm{d}} p$ : Primary vs comprehensive $<0.0001$. 
$\mathrm{p}<0.0001$ ); South America, $-17.4 \%$ (95\% CI -18.5 to $-16.3, p<0.0001$ ); Africa, $-30.2 \%$ (95\% CI -32.2 to -28.3 , $p<0.0001)$; whereas Oceania $(-1.9 \%$; $95 \% \mathrm{CI}-2.5$ to $-1.5, p$ $=0.3$ ) did not demonstrate significance (table e-1, doi.org/10. 5061/dryad.gljwstqpw). PSCs $-17.3 \%$ (95\% CI -17.9 to $-16.7, \mathrm{n}=89$ ) demonstrated greater declines compared to CSCs $-10.3 \%$ (95\% CI -10.6 to $-10.1, \mathrm{n}=236)($ table 1$)$.

\section{Thrombolysis}

IV thrombolytic volumes declined with 13,334 interventions in the prepandemic period vs 11,570 during the pandemic, representing a $13.2 \%$ drop (95\% CI -13.8 to $-12.7, p<0.001$; median [IQR] monthly IVT volume/center 6.5 [2.8-12.0] to 5.3 [2.0-10.5], $p<0.001, \mathrm{n}=389$ centers) (table 2, figure 2 ). IVT decline was seen in most continents: Asia, $-9.9 \%(95 \%$ CI -11.0 to $-8.9, \mathrm{p}<0.0001)$; North America, $-14.4 \%$ (95\% $\mathrm{CI}-15.6$ to $-13.3, p<0.0001$ ); Europe, $-13.5 \%$ (95\% CI
-14.4 to $-12.6, p<0.0001)$; South America, $-24.2 \%$ (95\% CI -27.6 to $-21.0, p<0.0001)$; Africa $-23.5 \%$ (95\% CI -29.8 to $-18.2, p<0.01)$. There was no appreciable difference in IVT in Oceania $-1.9 \%$ (95\% CI -3.9 to $-0.92, p=0.7)$ (table e-2, doi.org/10.5061/dryad.gljwstqpw). IVT declines were greater in PSCs $-15.5 \%$ (95\% CI -16.9 to $-14.2, \mathrm{n}=138$ centers) vs CSCs $-12.6 \%$ (95\% CI -13.3 to $-12.0, \mathrm{n}=251$ centers, $p=0.0001)$ (table 2).

\section{Recovery of Stroke and IVT Volume Analysis}

In the recovery analysis, there were 38,616 stroke hospitalizations in the early 2 months of the pandemic compared to 42,278 stroke hospitalizations in the later 2 pandemic months, representing an increase of 9.5\% (95\% CI 9.2-9.8, $p<0.0001$, $\mathrm{n}=325$ centers). The recovery in stroke hospitalization volume was seen in all strata of COVID-19 hospitalization burden, with a gradient of recovery more significant in low

Table 2 Tissue Plasminogen Activator (tPA) Procedure Volumes Immediately Before and During the Coronavirus Disease 2019 (COVID-19) Pandemic

\begin{tabular}{|c|c|c|c|c|c|c|c|c|c|c|}
\hline & \multicolumn{5}{|c|}{ Overall volume } & \multicolumn{5}{|c|}{ Monthly volume, median (IQR) } \\
\hline & $\mathbf{N}$ & n1 & n2 & $\begin{array}{l}\text { Relative (\%) } \\
\text { change, \% (95\% } \\
\text { CI) }\end{array}$ & $p$ Value & $\mathbf{N}$ & $\begin{array}{l}\text { Immediately } \\
\text { Before }\end{array}$ & $\begin{array}{l}\text { During } \\
\text { COVID-19 }\end{array}$ & $\begin{array}{l}\text { Difference }{ }^{a} \\
(95 \% \mathrm{Cl})\end{array}$ & $p$ Value \\
\hline Overall & 389 & 13,334 & 11,570 & $\begin{array}{l}-13.2(-13.8 \text { to } \\
-12.7)\end{array}$ & $<0.0001$ & 389 & $6.5(2.8-12.0)$ & $\begin{array}{l}5.3 \\
(2.0-10.5)\end{array}$ & $\begin{array}{l}-0.75(-1.0 \\
\text { to }-0.50)\end{array}$ & $<0.0001$ \\
\hline
\end{tabular}

\section{Hospital COVID-19}

volume $^{\mathrm{b}}$

\begin{tabular}{|c|c|c|c|c|c|c|c|c|c|c|}
\hline Low & 112 & 3,162 & 2,871 & $\begin{array}{l}-9.2(-10.3 \text { to } \\
-8.2)\end{array}$ & $<0.0001$ & 112 & $3.5(1.5-8.5)$ & $\begin{array}{l}3.1 \\
(1.3-8.1)\end{array}$ & $\begin{array}{l}-0.25(-0.50 \\
\text { to }-0.19)\end{array}$ & $<0.0001$ \\
\hline Intermediate & 102 & 3,373 & 2,947 & $\begin{array}{l}-12.6(-13.8 \text { to } \\
-11.6)\end{array}$ & $<0.0001$ & 102 & $6.3(3.3-13.0)$ & $\begin{array}{l}5.3 \\
(2.5-10.8)\end{array}$ & $\begin{array}{l}-0.75(-1.0 \\
\text { to }-0.25)\end{array}$ & $<0.0001$ \\
\hline High & 96 & 4,252 & 3,439 & $\begin{array}{l}-19.1(-20.3 \text { to } \\
-18.0)\end{array}$ & $<0.0001$ & 96 & $9.1(5.6-15.3)$ & $\begin{array}{l}7.5 \\
(4.0-12.5)\end{array}$ & $\begin{array}{l}-1.9(-2.5 \text { to } \\
-1.0)\end{array}$ & $<0.0001$ \\
\hline
\end{tabular}

\section{Hospital IV tPA}

volume $^{c}$

\begin{tabular}{|c|c|c|c|c|c|c|c|c|c|c|}
\hline Low & 133 & 1,052 & 929 & $\begin{array}{l}-11.7(-13.8 \text { to } \\
-9.9)\end{array}$ & 0.003 & 133 & $1.8(1.5-2.8)$ & $\begin{array}{l}1.3 \\
(1.0-2.5)\end{array}$ & $\begin{array}{l}-0.19(-0.25 \\
\text { to }-0.19)\end{array}$ & 0.007 \\
\hline Intermediate & 133 & 3,553 & 3,049 & $\begin{array}{l}-14.2(-15.4 \text { to } \\
-13.1)\end{array}$ & $<0.0001$ & 133 & $6.8(5.0-8.0)$ & $\begin{array}{l}5.3 \\
(3.8-7.3)\end{array}$ & $\begin{array}{l}-1.0(-1.5 \text { to } \\
-0.75)\end{array}$ & $<0.0001$ \\
\hline High & 123 & 8,729 & 7,592 & $\begin{array}{l}-13.0(-13.8 \text { to } \\
-12.3)\end{array}$ & $<0.0001$ & 123 & $\begin{array}{l}15.3 \\
(12.3-19.5)\end{array}$ & $\begin{array}{l}13.8 \\
(10.3-17.8)\end{array}$ & $\begin{array}{l}-2.3(-3.0 \text { to } \\
-1.5)\end{array}$ & $<0.0001$ \\
\hline
\end{tabular}

\section{Primary vs}

comprehensive stroke

center $^{\mathrm{d}}$

\begin{tabular}{|c|c|c|c|c|c|c|c|c|c|c|}
\hline Primary & 138 & 2,763 & 2,334 & $\begin{array}{l}-15.5(-16.9 \text { to } \\
-14.2)\end{array}$ & $<0.0001$ & 138 & $3.1(1.5-6.5)$ & $\begin{array}{l}2.1 \\
(1.3-5.5)\end{array}$ & $\begin{array}{l}-0.25(-0.75 \\
\text { to } 0.19)\end{array}$ & $<0.0001$ \\
\hline Comprehensive & 251 & 10,571 & 9,236 & $\begin{array}{l}-12.6(-13.3 \text { to } \\
-12.0)\end{array}$ & $<0.0001$ & 251 & $8.8(4.5-14.0)$ & $\begin{array}{l}7.3 \\
(3.5-12.8)\end{array}$ & $\begin{array}{l}-1.0(-1.3 \text { to } \\
-0.50)\end{array}$ & $<0.0001$ \\
\hline
\end{tabular}

Abbreviations: $\mathrm{Cl}$ = confidence interval; $\mathrm{IQR}$ = interquartile range; $\mathrm{N}$ = number of hospitals; $\mathrm{n}=$ number of procedures.

$\mathrm{n} 1$ and immediately before are based on 4 months before the pandemic (November 2019 to February 2020). n2 and during COVID-19 are based on March 2020 to June 2020. $p$ Values are from Poisson means test (overall volume analysis) and Wilcoxon signed-rank test (monthly volume analysis).

a Difference denotes the median difference between the 2 time periods.

${ }^{\mathrm{b}} \mathrm{p}$ : Low vs intermediate $<0.0001$; low vs high $<0.0001$; intermediate vs high $<0.0001$.

c $p$ : Low vs intermediate 0.038 ; low vs high 0.234 ; intermediate vs high 0.076 .

${ }^{\mathrm{d}} p$ : Primary vs comprehensive 0.0001. 


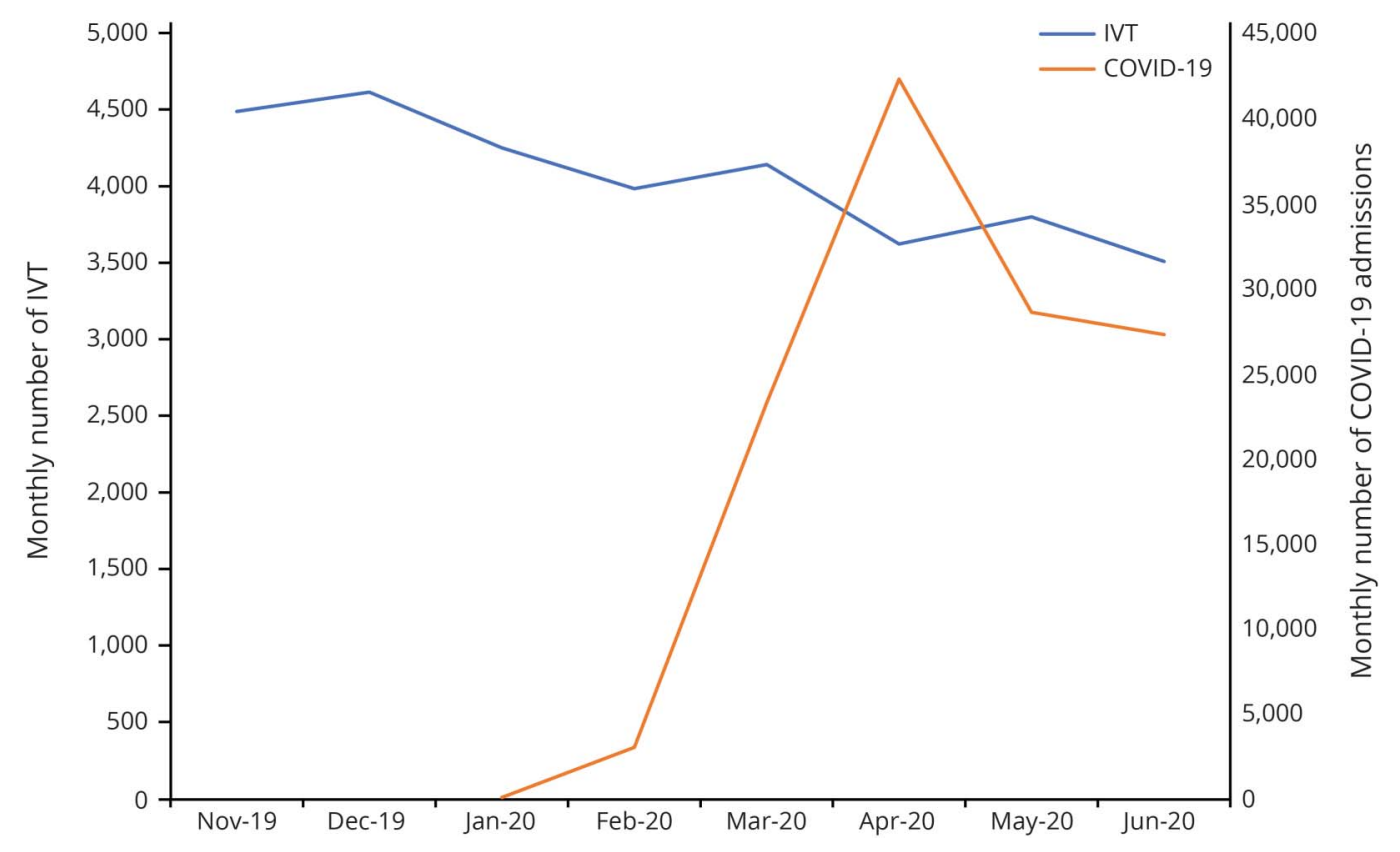

(14.6\%; 95\% CI 14.0-15.2, $p<0.0001)$ vs intermediate (9.0\%; 95\% CI 8.4-9.5, $p<0.0001)$ vs high-volume $(4.6 \%$; 95\% CI 4.2-5.0, $p<0.0001)$ COVID-19 hospitalization. There was a gradient in stroke hospitalization recovery by baseline hospital stroke volume, significant in high-volume (13.9\%; 95\% CI 13.5-14.3, $p<0.0001$ ) stroke centers compared to intermediate or low volume centers, which in their strata did not demonstrate significance in recovery. Stroke hospitalization volume recovery was more significant in CSCs (10.9\%; 95\% CI 10.6-11.3, $p<0.0001$ ) compared to PSCs (1.8\%; 95\% CI 1.5-2.1, $p=0.3)$ (table 3$)$.

IV thrombolysis was administered to 5,714 patients in the early pandemic compared to 5,856 patients in the later pandemic months, representing a nonsignificant increase of $2.5 \%$ (95\% CI 2.1-2.9, $p=0.19$ ). Recovery in IVT volume was more significant in intermediate $(6.1 \%, 95 \%$ CI $5.0-7.4)$ vs low $(2.6 \%$, 95\% CI 1.9-3.6, $p<0.0001)$ COVID-19 hospitalization centers. A trend in IVT volume recovery was seen with CSCs $(4.1 \%, 95 \%$ CI 3.6-4.7, $p=0.053)$.

\section{IVT Transfer Analysis}

There were 1,337 IVT transfers in the prepandemic compared to 1,178 in the pandemic months, representing an $11.9 \%$ drop (95\% CI -13.7 to $-10.3, p=0.001)$. The IVT transfer declines were significant in the strata of hospitals with low $(-18.3 \%$, $95 \% \mathrm{CI}-23.9$ to $-13.9, p=0.03)$ and high $(-14.9 \%, 95 \% \mathrm{CI}$ -18.1 to $-12.1, p=0.008$ ) COVID-19 volume (table 4$)$.

\section{Secondary Analysis}

Table 5 reveals the volumes for stroke hospitalizations, IVT, and IVT transfers during the first 4 months of the pandemic vs the corresponding period in the prior year. There were significant declines in the overall and monthly volumes for all metrics.

Intersection of COVID-19, SARS-CoV-2 Infection, and Stroke Hospitalizations

A total of 269 centers provided data on SARS-CoV-2 infection and diagnosis of stroke in the same patient. A diagnosis of any stroke was present in $1.48 \%(1778 / 119,967)$ of COVID-19 hospitalizations, with continental variation: Africa 1.6\% (47/ $2879)$, Asia $1.5 \%(317 / 20,858)$, Oceania $0.4 \%(1 / 257)$, Europe 1.4\% (507/36,871), North America 1.2\% (615/ 49,237), South America 3.0\% (291/9,865) (table e-5, doi. org/10.5061/dryad.gljwstqpw).

SARS-CoV-2 infection was present in 3.3\% $(1722 / 52,026)$ of stroke hospitalizations (table e-5, doi.org/10.5061/dryad. gljwstqpw) with continental variation: Africa 3.1\% (56/ 1828), Asia $2.7 \%(342 / 12,686)$, Oceania $0.1 \%$ (1/932), Europe 3.3\% (502/15,220), North America 3.0\% (527/ 17,855), South America 8.4\% (294/3,505) (table e-6, doi. org/10.5061/dryad.gljwstqpw).

\section{Discussion}

In this temporal analysis of more than 254,000 stroke hospitalizations worldwide, there was a global decrease in stroke admissions $(-11.5 \%)$, IV thrombolysis (-13.2\%), and IVT transfers $(-11.9 \%)$ during the first 4 pandemic months, compared to the immediately preceding period, confirming our primary hypothesis. A decrease in volume was also seen in relation to the equivalent period in the prior year for all metrics. The declines in both stroke 
Table 3 Stroke and IV Tissue Plasminogen Activator (tPA) Overall Volumes During Early and Late Coronavirus Disease 2019 (COVID-19) Pandemic

\begin{tabular}{|c|c|c|c|c|c|c|c|c|c|c|}
\hline & \multicolumn{5}{|c|}{ Stroke $^{a}$} & \multicolumn{5}{|c|}{ IV tPA ${ }^{b}$} \\
\hline & $\mathbf{N}$ & $\begin{array}{l}\text { Early } \\
\text { COVID-19 }\end{array}$ & $\begin{array}{l}\text { Late } \\
\text { COVID-19 }\end{array}$ & $\begin{array}{l}\text { Relative (\%) } \\
\text { change, \% (95\% } \\
\text { CI) }\end{array}$ & $p$ Value & $\mathbf{N}$ & $\begin{array}{l}\text { Early } \\
\text { COVID- } \\
19\end{array}$ & $\begin{array}{l}\text { Late } \\
\text { COVID- } \\
19\end{array}$ & $\begin{array}{l}\text { Relative }(\%) \\
\text { change, } \%(95 \% \mathrm{Cl})\end{array}$ & $\begin{array}{l}p \\
\text { Value }\end{array}$ \\
\hline Overall & 325 & 38,616 & 42,278 & 9.5 (9.2 to 9.8$)$ & $<0.0001$ & 389 & 5,714 & 5,856 & 2.5 (2.1 to -2.9$)$ & 0.187 \\
\hline \multicolumn{11}{|l|}{$\begin{array}{l}\text { Hospital COVID-19 } \\
\text { volume }\end{array}$} \\
\hline Low & 85 & 13,461 & 15,429 & $14.6(14.0$ to 15.2$)$ & $<0.0001$ & 112 & 1,417 & 1,454 & 2.6 (1.9 to 3.6$)$ & 0.490 \\
\hline Intermediate & 102 & 10,471 & 11,408 & 9.0 (8.4 to 9.5 ) & $<0.0001$ & 102 & 1,430 & 1,517 & 6.1 (5.0 to 7.4$)$ & 0.109 \\
\hline High & 91 & 10,712 & 11,201 & 4.6 (4.2 to 5.0$)$ & 0.001 & 96 & 1,717 & 1,722 & 0.29 (0.12 to 0.68$)$ & 0.932 \\
\hline \multicolumn{11}{|l|}{$\begin{array}{l}\text { Hospital stroke/IV } \\
\text { tPA volume }\end{array}$} \\
\hline Low & 113 & 4,468 & 4,483 & 0.34 (0.21 to 0.56$)$ & 0.874 & 133 & 464 & 465 & 0.22 (0.04 to 0.12 ) & 0.974 \\
\hline Intermediate & 108 & 9,604 & 9,845 & 2.5 (2.2 to 2.8 ) & 0.084 & 133 & 1,525 & 1,524 & 0.07 (0.01 to 0.38$)$ & 0.986 \\
\hline High & 104 & 24,544 & 27,950 & 13.9 (13.5 to 14.3$)$ & $<0.0001$ & 123 & 3,725 & 3,867 & 3.8 (3.2 to 4.5$)$ & 0.103 \\
\hline \multicolumn{11}{|l|}{$\begin{array}{l}\text { Primary vs } \\
\text { comprehensive } \\
\text { stroke center }\end{array}$} \\
\hline Primary & 89 & 6,057 & 6,165 & $1.8(1.5$ to 2.1$)$ & 0.329 & 138 & 1,189 & 1,145 & $-3.7(-2.8$ to -4.9$)$ & 0.363 \\
\hline Comprehensive & 236 & 32,559 & 36,113 & 10.9 (10.6 to 11.3$)$ & $<0.0001$ & 251 & 4,525 & 4,711 & 4.1 (3.6 to 4.7$)$ & 0.053 \\
\hline
\end{tabular}

Abbreviations: $\mathrm{Cl}=$ confidence interval; $\mathrm{N}$ = number of hospitals.

The early and late COVID-19 periods are based on March 2020 to April 2020 and May 2020 to June 2020, respectively. $p$ Value is from Poisson means test. ${ }^{a}$ Stroke volume analysis. Hospital COVID-19 volume: low vs intermediate $<0.0001$; low vs high $<0.0001$; intermediate vs high $<0.0001$. Hospital stroke volume: low vs intermediate $<0.0001$; low vs high $<0.0001$; intermediate vs high $<0.0001$. Primary vs comprehensive $<0.0001$.

b IV tPA volume analysis. Hospital COVID-19 volume: low vs intermediate $<0.0001$; low vs high $<0.0001$; intermediate vs high $<0.0001$. IV tPA volume: low vs intermediate 0.383 ; low vs high 0.0001 ; intermediate vs high $<0.0001$. Primary vs comprehensive $=$ NA.

hospitalization and IVT were greater in PSCs compared to CSCs. Recovery of stroke hospitalization volume (+9.5\%) was noted in the 2 subsequent months vs the 2 initial months of the pandemic, with greater recovery in hospitals with lower COVID-19 hospitalization volume, highvolume stroke centers, and CSCs.

Table 4 Tissue Plasminogen Activator (tPA) Transfer Volumes Immediately Before and During the Coronavirus Disease 2019 (COVID-19) Pandemic

\begin{tabular}{|c|c|c|c|c|c|c|c|c|c|c|}
\hline & \multicolumn{5}{|c|}{ Overall volume } & \multicolumn{5}{|c|}{ Monthly volume, median (IQR) } \\
\hline & $\mathbf{N}$ & n1 & n2 & $\begin{array}{l}\text { Relative (\%) change, \% } \\
(95 \% \mathrm{Cl})\end{array}$ & $\begin{array}{l}p \\
\text { Value }\end{array}$ & $\mathbf{N}$ & $\begin{array}{l}\text { Immediately } \\
\text { before }\end{array}$ & $\begin{array}{l}\text { During } \\
\text { COVID-19 }\end{array}$ & $\begin{array}{l}\text { Difference }^{a} \\
(95 \% \mathrm{Cl})\end{array}$ & $\begin{array}{l}p \\
\text { Value }\end{array}$ \\
\hline Overall & 39 & 1,337 & 1,178 & $-11.9(-13.7$ to -10.3$)$ & 0.001 & 39 & 7.5 (5.8 to 11.3 ) & $\begin{array}{l}7.3(5.0 \text { to } \\
9.5)\end{array}$ & $\begin{array}{l}-0.75(-1.3 \text { to } \\
0.0)\end{array}$ & 0.027 \\
\hline
\end{tabular}

\section{Hospital COVID-19}

volume $^{b}$

\begin{tabular}{|c|c|c|c|c|c|c|c|c|c|c|}
\hline Low & 7 & 229 & 187 & $-18.3(-23.9$ to -13.9$)$ & 0.032 & 7 & 6.5 (5.8 to 8.5 ) & $\begin{array}{l}6.8(6.5 \text { to } \\
7.5)\end{array}$ & $\begin{array}{l}-1.0(-9.8 \text { to } \\
1.8)\end{array}$ & 0.688 \\
\hline Intermediate & 14 & 428 & 404 & $-5.6(-8.2$ to -3.8$)$ & 0.341 & 14 & 7.5 (4.5 to 11.5 ) & $\begin{array}{l}7.5 \text { ( } 4.3 \text { to } \\
9.8)\end{array}$ & $\begin{array}{l}-0.38(-1.8 \text { to } \\
1.3)\end{array}$ & 0.352 \\
\hline High & 14 & 538 & 458 & $-14.9(-18.1$ to -12.1$)$ & 0.008 & 14 & 8.0 (6.0 to 11.3 ) & $\begin{array}{l}6.8 \text { (5.3 to } \\
9.5)\end{array}$ & $\begin{array}{l}-1.3(-2.5 \text { to } \\
1.3)\end{array}$ & 0.107 \\
\hline
\end{tabular}

Abbreviations: $\mathrm{Cl}=$ confidence interval; IQR = interquartile range; $\mathrm{N}=$ number of hospitals; $\mathrm{n}=$ number of transfers.

$\mathrm{n} 1$ and immediately before are based on 4 months before the pandemic (November 2019 to February 2020). n2 and during COVID-19 are based on March 2020 to June 2020. $p$ Values are from Poisson means test (overall volume analysis) and Wilcoxon signed-rank test (monthly volume analysis).

${ }^{a}$ Difference denotes the median difference between the 2 time periods.

${ }^{\mathrm{b}} p$ : Low vs intermediate $<0.0001$; low vs high 0.239 ; intermediate vs high $<0.0001$. 
Table 5 Overall and Monthly Volumes 1 Year Before and During Coronavirus Disease 2019 (COVID-19) Pandemic

\begin{tabular}{|c|c|c|c|c|c|c|c|c|c|c|}
\hline & \multicolumn{5}{|c|}{ Overall volume } & \multicolumn{5}{|c|}{ Monthly volume, median (IQR) } \\
\hline & $\mathbf{N}$ & n1 & n2 & $\begin{array}{l}\text { Relative }(\%) \text { change, \% } \\
(95 \% \mathrm{Cl})\end{array}$ & $p$ Value & $\mathbf{N}$ & $\begin{array}{l}1 \text { year } \\
\text { before }\end{array}$ & $\begin{array}{l}\text { During } \\
\text { COVID-19 }\end{array}$ & $\begin{array}{l}\text { Difference }{ }^{a} \\
(95 \% \mathrm{CI})\end{array}$ & $p$ Value \\
\hline Stroke & 297 & 82,465 & 72,554 & $-12.0(-12.2$ to -11.8$)$ & $<0.0001$ & 297 & $\begin{array}{l}50.3(28.3 \text { to } \\
80.8)\end{array}$ & $\begin{array}{l}42.0(24.3 \text { to } \\
70.3)\end{array}$ & $\begin{array}{l}-5.8(-7.8 \text { to } \\
-4.5)\end{array}$ & $<0.0001$ \\
\hline IV tPA & 377 & 12,527 & 11,198 & $-10.6(-11.2$ to -10.1$)$ & $<0.0001$ & 377 & $\begin{array}{l}6.0(2.3 \text { to } \\
12.0)\end{array}$ & $\begin{array}{l}5.3(2.0 \text { to } \\
10.5)\end{array}$ & $\begin{array}{l}-0.50(-0.75 \text { to } \\
-0.25)\end{array}$ & $<0.0001$ \\
\hline $\begin{array}{l}\text { IV tPA } \\
\text { transfer }\end{array}$ & 36 & 1,331 & 1,140 & $-14.4(-16.3$ to -12.6$)$ & $<0.0001$ & 36 & $\begin{array}{l}7.6(5.3 \text { to } \\
12.0)\end{array}$ & $\begin{array}{l}7.5 \text { (5.5 to } \\
9.5)\end{array}$ & $\begin{array}{l}-1.1(-2.0 \text { to } \\
0.25)\end{array}$ & 0.038 \\
\hline
\end{tabular}

Abbreviations: $\mathrm{Cl}=$ confidence interval; $\mathrm{IQR}=$ interquartile range; $\mathrm{N}=$ number of hospitals; $\mathrm{n}=$ number of admissions/procedures/transfers; tPA = tissue plasminogen activator.

$\mathrm{n} 1$ and 1 year before are based on 4-month data 1 year before the pandemic (March 2019 to June 2019). n2 and during COVID-19 are based on data from March 2020 to June 2020. $p$ Values are from Poisson means test (overall volume analysis) and Wilcoxon signed-rank test (monthly volume analysis).

a Difference denotes the median difference between the 2 time periods.

The decreases in the volume of stroke care provided were noted across centers with high, intermediate, and low COVID-19 hospitalization burden, and also across high, intermediate, and low volume stroke and IVT centers. As hypothesized, the magnitude of decrease of stroke hospitalizations and IVT was greater in centers with higher COVID-19 inpatient volumes.

Our results concur with other recent reports on the collateral effects of the COVID-19 pandemic on stroke systems of care including studies from China, ${ }^{11}$ Italy, ${ }^{15}$ Spain, ${ }^{10}$ France, ${ }^{12,16}$ Germany, ${ }^{17}$ Brazil, ${ }^{18}$ Canada, ${ }^{19}$ and the United States. ${ }^{9,20-22}$ Although prior analyses have described temporal and regional changes in stroke hospitalizations and IVT, this is among the first descriptions of the change at a global level, including primary and CSCs. Hospital access related to high COVID-19 burden was unlikely a factor, as the decline was seen in centers with few or no patients with COVID-19. ${ }^{23,24}$ Patient fear of contracting COVID-19 may have played a role, along with a decrease in presentation of TIA, mild, or moderate strokes, as reported by Diegoli et al. ${ }^{18}$ Physical distancing measures may have prevented patients from the timely witnessing of a stroke. Similar to cardiovascular events, it is conceivable that there was a true population-level reduction in cerebrovascular events, possibly related to decreased consumption of highsodium, fast foods, reduced exposure to ambient air pollution, or improvement in patient behaviors. ${ }^{24} \mathrm{~A}$ reduction in exposure to other common viruses that may play a role in triggering vascular events may have also reduced stroke risk.

In the recovery analysis, there was a gradient of recovery in stroke hospitalization in hospitals with lower compared to higher COVID-19 burden. CSCs and high-volume stroke centers demonstrated greater recovery, suggesting patients with a higher acuity of care needs seeking care in these comprehensive centers.

Our subgroup of 264 centers including 119,967 COVID-19 hospitalizations expands on prior mechanical thrombectomy analysis that was limited to CSCs (Nogueira) and represents the largest sample reporting the concomitant diagnoses of stroke and SARS-CoV-2 infection to date. Our $1.48 \%$ stroke rate in COVID-19 hospitalizations is similar to the pooled incidence of $1.1 \%-1.2 \%$ (range, $0.9 \%-2.7 \%$ ) of hospitalized patients with COVID-19. ${ }^{4}$ The higher rate may be explained in part by the higher number of patients contracting SARS$\mathrm{CoV}-2$ over time and higher availability of testing. Some variation in the proportions are expected given the different definitions (all strokes vs ischemic only) and populations involved (all hospitalized vs severely infected only) across studies. We also provide another perspective on this relationship by reporting an incidence of 3.3\% $(1722 / 52,026)$ for SARS-CoV-2 infection across all stroke hospitalizations among centers with documented COVID-19 hospitalization.

Finally, 25 years after the landmark National Institute of Neurological Disorders and Stroke trials showing the benefit of tPA, we learned from this global analysis that as of 2020, the availability of IVT for acute stroke therapy continues to be lacking in multiple countries in Africa (i.e., Nigeria, Kenya, Zimbabwe, Ghana, Ethiopia, Sudan) owing to its high cost and relative implementation complexity, limiting our analysis of temporal IVT treatment trends for this continent. This void highlights a disparity of access to basic stroke therapy in multiple low-income countries across the world.

To our knowledge, this is the largest global study to date evaluating the intersection of the COVID-19 pandemic with stroke care. Our study included the participation of diverse geography of centers from 6 continents, 70 countries, and 457 CSCs and PSCs.

Our study has several limitations. The diagnosis of stroke/ TIA in some centers was obtained using administrative coding of hospital ICD codes and hence there is a possibility of misclassification of diagnosis, potentially compounded by regional and national variations in stroke diagnosis and delivery of care. However, centers contributing to these data have systems to track stroke metrics of care, thus the relative 
changes in volume from this analysis are likely robust. Details on patient-level data including demographics, stroke subtypes, and clinical outcomes were not collected as these were outside the scope of the study. The definition of the pandemic period was arbitrary because the outbreak started and peaked at different times at different locations. This led to the computation of relative increases in volumes during the study period in the earlier affected regions, such as China, resulting in a potential underestimation of the global effect. Finally, the sampling varied with the availability of complete data in each subset of the analysis.

The COVID-19 pandemic was associated with an initial global decline in the volume of stroke hospitalizations, IVT, and interfacility IVT transfers. These reductions were observed regardless of COVID-19 hospitalization burden and prepandemic stroke and IVT volumes. PSCs and centers with higher COVID-19 inpatient volumes experienced steeper declines. Recovery of stroke hospitalization but not IVT volume was noted in the later phase of the pandemic months and associated with lower COVID-19 hospital burden, high volume, and CSCs. The findings of our study can inform future studies, preparedness, ${ }^{25-27}$ and local policies in the event of a second COVID-19 surge or future pandemic.

\section{Author Byline (Continued)}

Lenon Gwaunza, MBChB, MSc, Gift Wilson Ngwende, MBChB, FCP, David Sahakyan, MD, Aminur Rahman, MBBS, FCPS, MD, FINR, Zhibing Ai, MS, Fanghui Bai, MD, Zhenhui Duan, MD, MS, Yonggang Hao, MD, Wenguo Huang, MS, Guangwen Li, MD, Wei Li, MD, Ganzhe Liu, MD, Jun Luo, MD, MS, Xianjin Shang, MD, Yi Sui, MBBS, PhD, Ling Tian, MD, Hongbin Wen, MD, Bo $\mathrm{Wu}, \mathrm{MD}$, Yuying Yan, MD, Zhengzhou Yuan, MD, Hao Zhang, $\mathrm{MD}$, $\mathrm{PhD}$, Jun Zhang, $\mathrm{MD}$, Wenlong Zhao, $\mathrm{MD}$, Wenjie Zi, MD, Thomas W. Leung, MD, Chandril Chugh, MD, Vikram Huded, MD, Bindu Menon, MD, FRCP, Jeyaraj Durai Pandian, MD, PN Sylaja, MD, Fritz Sumantri Usman, Mehdi Farhoudi, MD, Elyar Sadeghi Hokmabadi, MD, Anat Horev, MD, Anna Reznik, MA, Rotem Sivan Hoffmann, MD, Nobuyuki Ohara, MD, Nobuyuki Sakai, MD, DMSc, Daisuke Watanabe, MD, PhD, Ryoo Yamamoto, MD, PhD, Ryosuke Doijiri, MD, Naoki Tokuda, MD, PhD, Takehiro Yamada, MD, Tadashi Terasaki, MD, Yukako Yazawa, MD, Takeshi Uwatoko, MD, Tomohisa Dembo, MD, PhD, Hisao Shimizu, MD, Yuri Sugiura, MD, Fumio Miyashita, MD, Hiroki Fukuda, MD, $\mathrm{PhD}$, Kosuke Miyake, MD, Junsuke Shimbo, $\mathrm{MD}, \mathrm{PhD}$, Yusuke Sugimura, MD, Yoshiki Yagita, MD, PhD, Yohei Takenobu, MD, PhD, Yuji Matsumaru, MD, PhD, Satoshi Yamada, MD, PhD, Ryuhei Kono, MD, Takuya Kanamaru, MD, PhD, Hidekazu Yamazaki, MD, Manabu Sakaguchi, MD, PhD, Kenichi Todo, MD, PhD, Nobuaki Yamamoto, MD, PhD, Kazutaka Sonoda, MD, Tomoko Yoshida, MD, Hiroyuki Hashimoto, MD, PhD, Ichiro Nakahara, MD, PhD, Aida Kondybayeva, MD, Kamila Faizullina, MD, PhD, Saltanat Kamenova, MD, Murat
Zhanuzakov, MD, Jang-Hyun Baek, MD, Yangha Hwang, MD, PhD, Jin Soo Lee, MD, Si Baek Lee, MD, Jusun Moon, MD, Hyungjong Park, MD, Jung Hwa Seo, MD, Kwon-Duk Seo, MD, Sung Il Sohn, MD, PhD, Chang Jun Young, MD, Rechdi Ahdab, MD, PhD, Wan Asyraf Wan Zaidi, MMed, Zariah Abdul Aziz, MMed, Hamidon bin Basri, MD, Law Wan Chung, MD, Aznita Binti Ibrahim, MMed, Khairul Azmi Ibrahim, MMed, Irene Looi, MBBS, Wee Yong Tan, MD, MRCP, Nafisah Wan Yahya, MMed, Stanislav Groppa, MD, PhD, Pavel Leahu, MD, Amal M. Al Hashmi, MD, Yahia Zakaria Imam, MBBS, MD, MRCP, Naveed Akhtar, MD, Maria Carissa Pineda-Franks, MD, Christian Oliver Co, MD, Dmitriy Kandyba, MD, Adel Alhazzani, MD, Hosam AlJehani, MBBS, MSc, Carol Huilian Tham, MBBS, MMed, MRCP, Marlie Jane Mamauag, MD, Narayanaswamy Venketasubramanian, FRCP, Chih-Hao Chen, MD, PhD, Sung-Chun Tang, MD, PhD, Anchalee Churojana, MD, Esref Akil, MD, özlem aykaç, MD, Atilla Ozcan Ozdemir, MD, Semih Giray, MD, Syed Irteza Hussain, MD, Seby John, MD, Huynh Le Vu, MD, Anh Duc Tran, MD, Huy Hoang Nguyen, MD, Thong Nhu Pham, MD, Thang Huy Nguyen, MD, Trung Quoc Nguyen, MD, Thomas Gattringer, $\mathrm{MD}$, $\mathrm{PhD}$, Christian Enzinger, $\mathrm{MD}$, Monika Killer-Oberpfalzer, MD, PhD, Flavio Bellante, MD, Sofie De Blauwe, MD, Geert Vanhooren, MD, Sylvie De Raedt, MD, $\mathrm{PhD}$, Anne Dusart, MD, Robin Lemmens, MD, PhD, Noemie Ligot, MD, Matthieu Pierre Rutgers, MD, Laetitia Yperzeele, MD, PhD, Filip Alexiev, MD, PhD, Teodora Sakelarova, MD, Marina Roje Bedeković, MD, PhD, Hrvoje Budincevic, $\mathrm{MD}, \mathrm{PhD}$, Igor Cindric, $\mathrm{MD}$, Zlatko Hucika, $\mathrm{MD}$, David Ozretic, MD, Majda Seferovic Saric, PhD, František Pfeifer, MD, Igor Karpowic, MD, David Cernik, MD, Martin Sramek, MD, Miroslav Skoda, MD, Helena Hlavacova, MD, Lukas Klecka, MD, Martin Koutny, MD, Daniel Vaclavik, MD, Ondrej Skoda, MD, Jan Fiksa, MD, Katerina Hanelova, MD, Miroslava Nevsimalova, MD, Robert Rezek, MD, Petr Prochazka, MD, Gabriela Krejstova, MD, Jiri Neumann, MD, Marta Vachova, MD, Henryk Brzezanski, MD, David Hlinovsky, MD, Dusan Tenora, MD, Rene Jura, MD, Lubomír Jurák, MD, Jan Novak, MD, Ales Novak, MD, Zdenek Topinka, MD, Petr Fibrich, MD, Helena Sobolova, MD, Ondrej Volny, MD, PhD, Hanne Krarup Christensen, MD, PhD, Nicolas Drenck, Bsc, Helle Klingenberg Iversen, MD DMSci, Claus Z. Simonsen, MD, PhD, Thomas Clement Truelsen, $\mathrm{MD}$, PhD, Troels Wienecke, $\mathrm{MD}$, $\mathrm{PhD}$, Riina Vibo, $\mathrm{MD}$, PhD, Katrin Gross-Paju, $\mathrm{MD}, \mathrm{PhD}$, Toomas Toomsoo, MD, PhD, Katrin Antsov, MD, Francois Caparros, $\mathrm{MD}$, MSc, Charlotte Cordonnier, $\mathrm{MD}$, PhD, Maria Dan, MD, Jean-Marc Faucheux, MD, Laura Mechtouff, MD, Omer Eker, MD, PhD, Emilie Lesaine, MD, Basile Ondze, MD, Roxane Peres, MD, Fernando Pico, MD, PhD, Michel Piotin, MD, PhD, Raoul Pop, MD, PhD, Francois Rouanet, MD, Tatuli Gubeladze, MD, PhD, Mirza Khinikadze, $\mathrm{MD}, \mathrm{PhD}$, Nino Lobjanidze, MD, Alexander Tsiskaridze, MD, PhD, Simon Nagel, MD, Peter Arthur Ringleb, MD, Michael Rosenkranz, MD, Holger 
Schmidt, MBBS, Annahita Sedghi, MD, Timo Siepmann, MD, Kristina Szabo, MD, Götz Thomalla, MD, Lina Palaiodimou, MD, Dimitrios Sagris, MD, Odysseas Kargiotis, MD, Peter Klivenyi, MD, PhD, Laszlo Szapary, MD, PhD, Gabor Tarkanyi, MD, Alessandro Adami, MD, Fabio Bandini, MD, Paolo Calabresi, MD, Giovanni Frisullo, MD, $\mathrm{PhD}$, Leonardo Renieri, MD, Davide Sangalli, MD, Anne Pirson, $\mathrm{MD}$, Maarten Uyttenboogaart, $\mathrm{MD}$, $\mathrm{PhD}$, Ido van den Wijngaard, MD, PhD, Espen Saxhaug Kristoffersen, MD, $\mathrm{PhD}$, Waldemar Brola, MD, PhD, Małgorzata Fudala, MD, PhD, Ewa Horoch-Lyszczarek, MD, Michal Karlinski, MD, $\mathrm{PhD}$, Radoslaw Kazmierski, MD, PhD, Pawel Kram, MD, Marcin Rogoziewicz, MD, PhD, Rafal Kaczorowski, MD, Piotr Luchowski, MD, Halina Sienkiewicz-Jarosz, MD, PhD, Piotr Sobolewski, MD, PhD, Waldemar Fryze, MD, PhD, Anna Wisniewska, MD, Malgorzata Wiszniewska, MD, PhD, Patricia Ferreira, MD, Paulo Ferreira, MD, Luisa Fonseca, MD, João Pedro Marto, MD, Teresa Pinho e Melo, MD, Ana Paiva Nunes, MD, Miguel Rodrigues, MD, MSc, Vítor Tedim Cruz, MD, PhD, Cristian FalupPecurariu, MD, PhD, Georgi Krastev, MD, PhD, Miroslav Mako, MD, María Alonso de Leciñana, MD, PhD, Juan F. Arenillas, MD, Oscar Ayo-Martin, MD, PhD, Antonio Cruz Culebras, MD, Exuperio Diez Tejedor, MD, PhD, Joan Montaner, $\mathrm{MD}, \mathrm{PhD}$, Soledad Pérez-Sánchez, $\mathrm{MD}, \mathrm{PhD}$, Miguel Angel Tola Arribas, MA, MD, PhD, Alejandro Rodriguez Vasquez, MD, Michael Mayza, MD, PhD, Gianmarco Bernava, MD, Alex Brehm, MD, Paolo Machi, MD, PhD, Urs Fischer, MD, MSc, Jan Gralla, MD, Patrik L. Michel, MD, Marios-Nikos Psychogios, MD, Davide Strambo, MD, Soma Banerjee, MD, Kailash Krishnan, MRCP, PhD, Joseph Kwan, MD, MPhil, FRCP, Asif Butt, MBBS, Luciana Catanese, MD, Andrew M. Demchuk, MD, Thalia Field, MD, MHSc, Jennifer Haynes, RN, Michael D. Hill, MD, MSc, Houman Khosravani, $\mathrm{MD}, \mathrm{PhD}$, Ariane Mackey, $\mathrm{MD}$, Aleksandra Pikula, MD, Gustavo Saposnik, MD, MPH, FRCPc, Courtney Anne Scott, MD, Ashkan Shoamanesh, MD, Ashfaq Shuaib, MD, Samuel Yip, MD, $\mathrm{PhD}$, Miguel A. Barboza, MD, MSc, Jose Domingo Barrientos, MD, MSc, Ligia Ibeth Portillo Rivera, MD, Fernando Gongora-Rivera, MD, MSc, Nelson NovarroEscudero, MD, MSc, Anmylene Blanco, MD, Michael Abraham, MD, Diana Alsbrook, MD, Dorothea Altschul, MD, Anthony J. Alvarado-Ortiz, DO, Ivo Bach, MD, Aamir Badruddin, MD, Nobl Barazangi, MD, PhD, Charmaine Brereton, RN, MSN, Alicia Castonguay, $\mathrm{PhD}$, Seemant Chaturvedi, MD, Saqib A. Chaudry, MD, Hana Choe, MD, Jae H. Choi, MD, Sushrut Dharmadhikari, MD, Kinjal Desai, MD, MPH, Thomas G. Devlin, MD, PhD, Vinodh T. Doss, MD, Randall Edgell, MD, Mark Etherton, $\mathrm{MD}, \mathrm{PhD}$, Mudassir Farooqui, MBBS, Don Frei, MD, Dheeraj Gandhi, MD, Mikayel Grigoryan, MD, Rishi Gupta, MD, Ameer E. Hassan, DO, Johanna Helenius, MD, PhD, Artem Kaliaev, MD, Ritesh Kaushal, MD, PhD, Priyank Khandelwal, MD, Ayaz M. Khawaja, MD, Naim N. Khoury, MD, MS, Benny S. Kim, MD, Dawn O. Kleindorfer, MD, Feliks Koyfman, MD, Vivien H. Lee, MD,
Lester Y. Leung, MD, MSc, Guillermo Linares, MD, Italo Linfante, MD, Helmi L. Lutsep, MD, Lisa Macdougall, RN, MS, Shailesh Male, MD, Amer M. Malik, MD, Hesham Masoud, MD, Molly McDermott, MD, Brijesh P. Mehta, MD, Jiangyong Min, MD, PhD, Manoj Mittal, MD, Jane G. Morris, MD, Sumeet S. Multani, MD, Fadi Nahab, MD, Krishna Nalleballe, MD, Claude B. Nguyen, MD, Roberta Novakovic-White, MD, Santiago Ortega-Gutierrez, MD, Rahul H. Rahangdale, MD, Pankajavalli Ramakrishnan, MD, PhD, Jose Rafael Romero, MD, Natalia Rost, MD, Aaron Rothstein, MD, Sean Ruland, DO, Ruchir Shah, MD, Malveeka Sharma, MD, Brian Silver, MD, Marc Simmons, MD, Abhishek Singh, MD, Amy K. Starosciak, PhD, Sheryl L. Strasser, MD, Viktor Szeder, MD, PhD, Mohamed Teleb, MD, Jenny P. Tsai, MD, Barbara Voetsch, MD, PhD, Oscar Balaguera, MD, Virginia A. Pujol Lereis, MD, Adriana Luraschi, MD, Marcele Schettini Almeida, MD, Fabricio Buchdid Cardoso, MD, Adriana Conforto, MD, Leonardo De Deus Silva, MD, Luidia Varrone Giacomini, MD, Fabricio Oliveira Lima, $\mathrm{MD}, \mathrm{MPH}, \mathrm{PhD}$, Alexandre L. Longo, MD, Pedro S.C. Magalhães, MD, Rodrigo Targa Martins, MD, Francisco Mont'alverne, MD, PhD, Daissy Liliana Mora Cuervo, MD, Leticia Costa Rebello, MD, Lenise Valler, MD, Viviane Flumignan Zetola, MD, PhD, Pablo M. Lavados, MD, $\mathrm{MPH}$, Victor Navia, MD, Verónica V. Olavarría, MD, Juan Manuel Almeida Toro, MD, Pablo Felipe Ricardo Amaya, Hernan Bayona, MD, Angel Corredor, MD, Carlos Eduardo Rivera Ordonez, MD, Diana Katherine Mantilla Barbosa, MD, Osvaldo Lara, MD, MSc, Mauricio R. Patiño, MD, Luis Fernando Diaz Escobar, MD, Donoband Edson Dejesus Melgarejo Fariña, MD, Analia Cardozo Villamayor, MD, Adolfo Javier Zelaya Zarza, MD, Danny Moises Barrientos Iman, MD, Liliana Rodriguez Kadota, MD, Bruce Campbell, MBBS, PhD, Graeme J. Hankey, MD, Casey Hair, Timothy Kleinig, $\mathrm{MD}$, $\mathrm{PhD}$, Alice Ma, MBBS, Rodrigo Tomazini Martins, MD, PhD, Ramesh Sahathevan, Vincent Thijs, MD, Daniel Salazar, MD, PhD, FRACP, Teddy YuanHao $\mathrm{Wu}, \mathrm{MD}, \mathrm{PhD}$, Diogo C. Haussen, MD, David Liebeskind, MD, Dileep R. Yavagal, MD, Tudor G. Jovin, MD, Osama O. Zaidat, MD, Thanh N. Nguyen, MD

\section{Affiliation}

Department of Neurology (R.G.N., M.H.M., M.Frankel, D.C.H.), Marcus Stroke and Neuroscience Center, Grady Memorial Hospital, Emory University School of Medicine, Atlanta; Department of Radiology (M.M.Q., M.A., T.N.N., A.K.) and Radiation Oncology (M.M.Q.), Boston Medical Center, Boston University School of Medicine, Massachusetts; Department of Neurology (S.O.M.), Federal University of Rio Grande do Sul, Porto Alegre; Hospital de Clínicas de Porto Alegre (S.O.M.), Brazil; Department of Stroke Neurology (H. Yamagami), National Hospital Organization, Osaka National Hospital, Japan; Department of Neurology (Z.Q.), Xinqiao Hospital of the Army Medical University, Chongqing, China; Department of Neurology (O.Y.M.), Stroke and Neurointervention Division, Alexandria University Hospital, Alexandria University, Egypt; Boston University School of Medicine (A.S.), Massachusetts; 2nd Department of Neurology (A.C.), Institute of Psychiatry and Neurology, Warsaw, Poland; Department of Neurology (G.T., L.P.), National \& Kapodistrian University of Athens, School of Medicine, Attikon University Hospital, Athens, Greece; Faculdade de Medicina (D.A.d.S.), Universidade de Lisboa, Lisbon, Portugal; Department of Neurology (J.D., R.L.), Leuven University Hospital, Belgium; International Clinical Research Center an Department of Neurology (R.M.), St. Anne's University Hospital in Brno and Faculty of Medicine, Masaryk University, Brno, Czech Republic; Department of Neurology (P.V.), Groeninge Hospital, Kortrijk; Department of Neurology (P.V.), University Hospitals Antwerp; Department of Translational Neuroscience (P.V.), University of Antwerp, Belgium; Department of Neurology (J.E.S., T.G.J.), Cooper Neurological Institute, Cooper University Hospital, Camden, New Jersey; Department of Neurology and Neurosurgery (J. Kõrv), University of Tartu, Estonia; Department of Neurology (J.B., R.V.,S.R.), Loyola University Chicago Stritch School of Medicine, Illinois; Department of Neurosurgery (C.W.L.), Kaiser Permanente Fontana Medical Center; Department of Neurology (N.S.S.), Kaiser Permanente Los Angeles Medical 
Center; Department of Neurology (A.M.Z., S.A.S.), UT Health McGovern Medical School, Houston, Texas; Department of Neurology (A.L.Z.), Medical University of South Carolina, Charleston; Department of Internal Medicine (G.N.), School of Health Sciences, University of Thessaly, Larissa, Greece; Department of Neurology (K.M., A.T.), Allegheny Health Network, Pittsburgh, Pennsylvania; Department of Neurology (A.L.), Ohio Health Riverside Methodist Hospital Columbus; Department of Medicine and Neurology (A.R.), University of Otago and Wellington Hospital, New Zealand; Department of Neurology (E.A.M.), Vanderbilt University Medical Center, Nashville, Tennessee; Department of Neurology (A.W.A., D. Alsbrook), University of Tennessee Health Center, Memphis; Department of Neurology (D.Y.H.), University of North Carolina at Chapel Hill; Departments of Neurology (S.Y.) and Radiology (E.R.), New York University Grossman School of Medicine; Douala Gynaeco-Obstetric and Pediatric Hospital (E.G.B.L.), University of Douala, Faculty of Medicine and Pharmaceutical Science, Cameroon; Ain Shams University Specialized Hospital (H.M.A., H.M.S., A.E., T.R.); Cairo University Affiliated MOH Network (F.H.); Department of Neurology (TM.), Nasser Institute for Research and Treatment, Cairo; Mansoura University Affiliated Private Hospitals Network (W.M.), Egypt; Kwame Nkrumah University of Science and Technology (F.S.S.), Kumasi, Ghana; Stroke Unit (T.O.A., K.W.), University of Ilorin Teaching Hospital; Neurology Unit (B.A.), Department of Medicine, Lagos State University Teaching Hospital; Department of Medicine (E.O.N.), Federal Medical Centre Owerri, Imo State, Nigeria; Neurology Unit (T.A.S.), Department of Medicine, Federal Medical Centre, Owo, Ondo State, Nigeria; University College Hospital (J.Y.), Ibadan, Nigeria; The National Ribat University Affiliated Hospitals (H.H.M.), Khartoum, Sudan; Neurology Section (P.B.A.), Department of Internal Medicine, Aga-Khan University, Medical College East Africa, Dar es Salaam, Tanzania; Tunis El Manar University (A.D.R.), Military Hospital of Tunis; Department of Neurology (S.B.S.), Mongi Ben Hmida National Institute of Neurology, Faculty of Medicine of Tunis, University Tunis El Manar, Tunisia; Department of Physiology (L.G.), Parirenyatwa Hospital, and Departments of Physiology and Medicine (G.W.N.), University of Zimbabwe, Harare; Department of Cerebrovascular/Endovascular Neurosurgery Division (D.S.), Erebouni Medical Center, Yerevan, Armenia; Department of Neurology (A.R.), Sir Salimulah College, Dhaka, Bangladesh; Department of Neurology (Z.A.), Taihe Hospital of Shiyan City, Hubei; Department of Neurology (F.B.), Nanyang Central Hospital, Henan; Department of Neurology (Z.D.), Wuhan No. 1 Hospital, Hubei, China; Department of Neurology (Y. Hao.), Sir Run Run Shaw Hospital, Zhejiang University School of Medicine; Department of Neurology (W.H.), Traditional Chinese Medicine Hospital of Maoming, Guangdong; Department of Neurology (G.Li.), Affiliated Hospital of Qingdao University, Shandong; Department of Neurology (W.L), The First Affiliated Hospital of Hainan Medical College; Department of Neurology (G.Liu.), Wuhan Central Hospital, Hubei; Department of Neurology (J.L.), Mianyang 404th Hospital, Sichuan; Department of Neurology (X.S.), Yijishan Hospital of Wannan Medical College, Anhui; Department of Neurology and Neuroscience (Y.S.), Shenyang Brain Institute, Shenyang First People's Hospital, Shenyang Medical College Affiliated Brain Hospital; Department of Neurology (L.T.), Affiliated Yantai Yuhuangding Hospital of Qingdao University, Shandong; Department of Neurology (H.W.), Xiangyang Central Hospital, Hubei; Department of Neurology (B.W., Y.Yan), West China Hospital, Sichuan University, Chengdu; Department of Neurology (Z.Y.), Affiliated Hospital of Southwest Medical University, Sichuan; Department of Neurology (H.Z.), Affiliated Hangzhou First People's Hospital, Zhejiang University School of Medicine; Department of Neurology (J.Z.), The First Affiliated Hospital of Shandong First Medical University; Department of Neurology (W.Z.), First Affiliated Hospital of Fujian Medical University, China; Acute Stroke Unit (T.W.L.), The Prince of Wales Hospital, Kwok Tak Seng Centre for Stroke Research and Intervention, The Chinese University of Hong Kong; Interventional Neurology (C.C.), MAX Superspecialty Hospital, Saket, New Delhi; NH Institute of Neurosciences (V.H.), NH Mazumdar Shaw Medical Center, Bangalore, Department of Neurology (B.M.), Apollo Speciality Hospitals Nellore; Department of Neurology (J.D.P.), Christian Medical College, Ludhiana, Punjab; Sree Chitra Tirunal Institute for Medical Sciences and Technology (P.N.S.), Kerala, India; Stroke Unit (F.S.U.), Pelni Hospital, Jakarta, Indonesia; Neurosciences Research Center (M. Farhoudi, E.S.H.), Tabriz University of Medical Sciences, Tabriz, Iran; Beer Sheva Hospital (A.H.); Department of Interventional Neuroradiology, Rambam Healthcare Campus, Haifa, Israel (A.R., R.S.H.); Departments of Neurology (N.O.) and Neurosurgery (N.S.), Kobe City Medical Center General Hospital, Kobe; Department of Stroke and Neurovascular Surgery (D.W.), IMS Tokyo-Katsushika General Hospital; Yokohama Brain and Spine Center (R.Y.); Iwate Prefectural Central (R.D.); Department of Neurology and Stroke Treatment (N.T.), Japanese Red Cross Kyoto Daiichi Hospital; Department of Neurology (T.Y.), Kyoto Second Red Cross Hospital; Department of Neurology (T.T.), Japanese Red Cross Kumamoto Hospital; Department of Stroke Neurology (Y. Yazawa), Kohnan Hospital, Sendai; Department of Cerebrovascular Medicine (T.U.), Saga-Ken Medical Centre; Department of Neurology (T.D.), Saitama Medical Center, Kawagoe; Department of Neurology (H.S.), Nara City Hospital; Department of Neurology (Y.S.), Toyonaka Municipal Hospital, Osaka; Department of Neurology (F. Miyashita), Kagoshima City Hospital; Department of Neurology (H.F.), Japanese Red Cross Matsue Hospital, Shimane; Department of Neurology (K.M.), Shiroyama Hospital, Osaka; Department of Cerebrovascular Medicine (J.E.S.), Niigata City General Hospital; Department of Neurology (Y.S.), Sugimura Hospital, Kumamoto; Stroke Medicine (Y. Yagita), Kawasaki Medical School, Okayama; Department of Neurology (Y.T.), Osaka Red Cross Hospital; Department of Stroke Prevention and Treatment (Y.M.), Department of Neurosurgery, University of Tsukuba, Ibaraki; Department of Neurology (S.Y.), Stroke Center and Neuroendovascular Therapy, Saiseikai Central Hospital, Tokyo; Department of Neurology (R.K.), Kin-ikyo Chuo Hospital, Hokkaido; Department of Cerebrovascular Medicine (T.K.), NTT Medical Center Tokyo; Department of Neurology and Neuroendovascular Treatment (H. Yamazaki), Yokohama Shintoshi Neurosurgical Hospital; Department of Neurology (M.S.), Osaka General Medical Center; Department of Neurology (K.T.), Osaka University Hospital; Department of Advanced Brain Research (N.Y.), Tokushima University Hospital Tokushima; Department of Neurology (K.S.), Saiseikai Fukuoka General Hospital, Fukuoka; Department of Neurology (T.Y.), Tane General Hospital, Osaka; Division of Stroke (H.H.), Department of Internal Medicine, Osaka Rosai Hospital; Department of Comprehensive Stroke (I.N.), Fujita Health University School of Medicine, Toyoake, Japan; Department of Neurology (A.K.), Asfendiyarov Kazakh National Medical University; Republican Center for eHealth (K.F.), Ministry of Health of the Republic of Kazakhstan, Department of Medicine (S.K.), Al-Farabi Kazakh National University; Kazakh-Russian Medical University (M.Z.), Kazakhstan; Department of Neurology (J.-H.B.), Kangbuk Samsung Hospital, Sungkyunkwan University School of Medicine, Seoul; Department of Neurology (Y. Hwang), Kyungpook National University Hospital, School of Medicine, Kyungpook National University; Ajou University Hospital (J.S.L.); Department of Neurology (S.B.L.), Uijeongbu St. Mary's Hospital, College of Medicine, The Catholic University of Korea; Department of Neurology (J.M.), National Medical Center, Seoul; Department of Neurology (H.P., S.I.S.), Keimyung University School of Medicine, Dongsan Medical Center, Daegu; Department of Neurology (J.H.S.), Busan Paik Hospital, School of Medicine, Inje University, Busan; Department of Neurology (K.-D.S.), National Health Insurance Service Ilsan Hospital, Goyang; Asan Medical Center (C.J.Y.), Seoul, South Korea; Department of Neurology (R.A.), LAU Medical Center-Rizk Hospital, Beirut, Lebanon; Department of Medicine (W.A.W.Z., N.W.Y.), Pusat Perubatan Universiti Kebangsaan Malaysia, Kuala Lumpur; Sultanah Nur Zahirah (Z.A.A., K.A.I.), Kuala Terengganu; University Putra Malaysia (H.b.B.); Sarawak General Hospital, Kuching (L.W.C.); Hospital Sultan Abdul Halim
(A.B.I.), Sungai Petani Kedah; Hospital Seberang Jaya (I.L.), Pulau Pinang; Thomson Hospital Kota Damansara (W.Y.T), Malaysia; "Nicolae Testemitanu" State University of Medicine and Pharmacy (S.G P.L.), and Department of Neurology, Emergency Medicine Institute, Chisinau, Republic of Moldova; Department of Stroke Unit (A.M.A.H.), Royal Hospital Muscat, Oman; Neuroscience Institute (Y.Z.I N.A.), Hamad Medical Corporation, Doha, Qatar; St. Luke's Medical Center-Institute of Neurosciences (M.C.P.-F., C.O.C.), Quezon City, Philippines; Endovascular Neurosurgery (D.K.), Saint-Petersburg Dzhanelidze Research Institute of Emergency Medicine, St. Petersburg, Russia; Department of Neurology (A.A.), Stroke Unit, King Saud University, College of Medicine, Riyadh; Department of Neurosurgery (H.A.-J.), Interventional Radiology, and Critical Care Medicine, King Fahad Hospital of the University, Imam Abdulrahman bin Faisal University, Saudi Arabia; Singapore National Neuroscience Institute (C.H.T.); Changi General Hospital (M.J.M.), Singapore; Neuroscience Center, Raffles Hospital (N.V.), Singapore; Department of Neurology (C.-H.C., S.-C.T.), National Taiwan University Hospital; Department of Radiology (A.C.), Faculty of Medicine Siriraj Hospital, Mahidol University, Bangkok, Thailand; Dicle University Medical School and Hospital (E.A.), Diyarbakir; Stroke and Neurointervention Unit (O.A. A.O.O.), Eskisehir Osmangazi University; Gaziantep University Faculty of Medicine (S.G.), Turkey; Department of Neurology (S.I.H., S.J.), Neurological Institute at Cleveland Clinic Abu Dhabi, United Arab Emirates; Stroke Center (H.L.V., A.D.C.), Hue Central Hospital, Hue, Vietnam; Stroke Department (H.H.N., T.N.P.), Da Nang Hospital, Da Nang City; 115 People's Hospital (T.H.N., T.Q.N.), Ho Chi Minh City, Vietnam; Department of Neurology (T.G., C.E.), Medical University of Graz; Department of Neurology (M. K.-O.), Research Institute of Neurointervention, University Hospital Salzburg/Paracelsus Medical University, Austria; Department of Neurology (F.B., A.D.), Centre Hospitalier Universitaire de Charleroi, Belgium; Department of Neurology (S.D.B., G.V.), Sint Jan Hospital, Bruges; Department of Neurology (S.D.R.), Brussels University Hospital (UZ Brussel); Department of Neurology (N.L.), ULB Erasme Hospitals Brussels; Department of Neurology (M.P.R.), Europe Hospitals Brussels; Department of Neurology (L.Y.), Antwerp University Hospital, Belgium; Neurology Clinic (F.A., T.S.), St. Anna University Hospital, Sofia, Bulgaria; Department of Neurology (M.R.B.), Sestre Milosrdnice University Hospital, Zagreb; Department of Neurology (H.B.), Sveti Duh University Hospital, Zagreb; Department of Neurology (I.C.), General Hospital Virovitica; Department of Neurology (Z.H.), General Hospital Zabok; Departmen of Radiology (F. Pfeifer), University Hospital Centre Zagreb, Croatia; Regional Hospital Karlovy Vary (I.K.); Masaryk Hospital Usti nad Labem (D.C.); Military University Hospital Praha (M. Sramek); Oblastní Nemocnice Náchod (M. Skoda); Regional Hospital Pribram (H.H.); Municipal Hospital Ostrava (L.K.) Hospital Mlada Boleslav (M. Koutny); Hospital Vitkovice (D.V.); Hospital Jihlava (O.S.); General University Hospital Praha (J.F.); Hospital Litomysl (K.H.); Hospital České Budejovice (M.N.); Hospital Pisek (R.R.); Hospital Uherske Hradiste (P.P.); Hospital Prostejov (G.K.); Regional Hospital Chomutov (J.N.); Hospital Teplice (M.V.); Mining Hospital Karvina (H.B.); Thomayer Hospital Praha (D.H.); Hospital Blansko (D.T.); University Hospital Brno (R.J.); Regional Hospital Liberec (L.J.); Hospital Ceska Lipa (J.N.); Hospital Sokolov (A.N.); Regional Hospital Kolin (Z.T.); Hospital Trutnov (P. Fibrich); Hospital Trinec (H.S.); Department of Neurology (O.V.), University Hospital Ostrava, Faculty of Medicine, Masaryk University, Brno, Czech Republic; Bispebjerg Hospital (H.K.C.), University of Copenhagen; Stroke Center (H.K.I., T.C.T.), Rigshospitalet, University of Copenhagen; Aarhus University Hospital (C.Z.S.), Aarhus Neurovascular Center, Zealand University Hospital, University of Copenhagen (T.W.), Roskilde, Denmark Department of Neurology and Neurosurgery (R.V.), University of Tartu, Estonia; Neurology Clinic (K.G.P.), West Tallinn Central Hospital; Center of Neurology (T.T.), East Tallinn Central Hospital, School of Natural Sciences and Health, Tallinn University; Internal Medicine Clinic (K.A.), Pärnu Hospital, Estonia; Université Lille, Inserm, CHU Lille, Lille Neuroscience \& Cognition (C.C., F.C.); Centre Hospitalie d'Arcachon (M.D.), Gujan-Mestras; Centre Hospitalier d'Agen (J.-M.F.); Neurologie Vasculaire (L.M.) and Neuroradiologie (O.E.), Hospices Civils de Lyon, Hôpital Pierre Wertheimer, Bron; Centre Hospitalier e Universitaire de Bordeaux (E.L., F.R.); Centre Hospitalier de Mont de Marsan (B.O.); Neurologie (R.P.), Fondation Ophtalmologique Adolphe de Rothschild; Versailles Saint-Quentin-en-Yvelines University (F. Pico); Neuroradiologie Interventionelle (M.P.), Fondation Ophtalmologique Adolphe de Rothschild, Neuroradiologie Interventionelle (R.P.), Hôpitaux Universitaires de Strasbourg, France; K. Eristavi National Center of Experimental and Clinical Surgery (T.G.), Tbilisi; Department of Neurosurgery (M. Khinikadze), New Vision University Hospital, Tbilisi; Vivamedi Medical Center (M. Khinikadze), Tbilisi; Pineo Medical Ecosystem (N.L.), Tbilisi; Ivane Javakhishvili Tbilisi State University (A.T.), Tbilisi, Georgia; Department of Neurology (S.N., P.A.R.), University Hospital Heidelberg; Department of Neurology (M. Rosenkranz), Albertinen Krankenhaus, Hamburg; Department of Neurology (H.S.), Elbe Klinken Stade, University Medical Center Göttingen; Department of Neurology (T.S.), University Hospital Carl Gustav Carus, Dresden; Kristina Szabo (K.S.), Department of Neurology, Medical Faculty Mannheim, University Heidelberg, Mannheim; Klinik und Poliklinik für Neurologie (G.T.), Kopf- und Neurozentrum, Universitätsklinikum Hamburg-Eppendorf, Germany; Department of Internal Medicine (D.S.), School of Health Sciences, University of Thessaly, Larissa; Second Department of Neurology (O.K.), Stroke Unit, Metropolitan Hospital, Piraeus, Greece; University of Szeged (P.K.), Szeged; University of Pecs (L.S., G.T.), Hungary; Stroke Center (A.A.), IRCCS Istituto di Ricovero e Cura a Carattere Scientifico, Negrar, Verona Department of Neurology (F.B.), Ospedale San Paolo, Savona,; Institute of Neurology (P.C., G.F.), Fondazione Policlinico Universitario Agostino Gemelli, Rome; Interventional Neurovascular Unit (L.R.) Careggi University Hospital, Florence; Stroke Unit (D.S.), Azienda Socio Sanitaria Territoriale (ASST) di Lecco, Italy; Maastricht University Medical Center; Department of Neurology (M.U.), Radiology, University Medical Center Groningen; Department of Neurology (I.v.d.W.), Haaglanden Medical Center, the Hague, the Netherlands; Department of Neurology (E.S.K.), Akershus University Hospital, Lørenskog, General Practice, HELSAM, University of Oslo, Norway; Neurological Ward with Stroke Unit (W.B.) Specialist Hospital in Konskie, Gimnazjalna, Poland and Collegium Medicum, Jan Kochanowski University, Kielce, Poland; Neurological Ward with Stroke Unit (M.F.), District Hospital in Skarzysko-Kamienna; Department of Neurology (E.H.L.), Szpitala im T. Marciniaka in Wroclaw; 2nd Department of Neurolog (M. Karlinski), Institute of Psychiatry and Neurology, Warsaw; Department of Neurology and Cerebrovascular Disorders (R.K., P.K.), Poznan University of Medical Sciences; 107th Military Hospital with Polyclinic (M.R.), Walcz; Department of Neurology (R.K.), St. Queen Jadwiga, Clinical Regional Hospital No. 2, Rzeszow; Department of Neurology (P.L.), Medical University of Lublin; 1st Department of Neurology (H.S.-J.), Institute of Psychiatry and Neurology, Warsaw; Department of Neurology and Stroke Unit (P.S.), Holy Spirit Specialist Hospital in Sandomierz, Collegium Medicum Jan Kochanowski University in Kielce; Copernicus PL (W.F.), Neurology and Stroke Department, Hospital M. Kopernik, Gdansk; Stroke Unit (M.W.), Neurological Department, Stanislaw Staszic University of Applied Sciences, Pila, Poland, Hospital São José (Patricia Ferreira), Centro Hospitalar Universitário de Lisboa Central, Lisbon; Stroke Unit (Paulo Ferreira, V.T.C.), Hospital Pedro Hispano, Matosinhos; Stroke Unit, Internal Medicine Department (L.F.), Neuroradiology Department, Centro Hospitalar Universitário de São João, Porto; Department of Neurology (J.P.M.), Hospital de Egas Moniz, Centro Hospitalar Lisboa Ocidental, Lisbon, Portugal; Department of Neurosciences (T.P.e.M.), Hospital de Santa Maria-CHLN, North Lisbon University Hospital, Hospital São José (A.P.N.), Centro Hospitalar Universitário de Lisboa Central, Lisbon; Department of Neurology (M. Rodrigues), Hospital Garcia de Orta, Portugal; Department of Neurology (C.F.-P.), 
Transilvania University, Brasov, Romania; Department of Neurology (G.K., M. Mako), Faculty Hospital Trnava, Slovakia; Department of Neurology and Stroke Center (M.A.d.L, E.D.T.), Hospital Universitario L Paz, Madrid; Department of Neurology (J.F.A.), Hospital Clínico Universitario, Universidad de Valladolid; Department of Neurology (O.A.-M.), Complejo Hospitalario Universitario de Albacete; Department of Neurology (A.C.C.), Unidad de Ictus, Hospital Universitario Ramon y Cajal, Madrid; Department of Neurology (S.P.-S), Hospital Universitario Virgen Macarena \& Neurovascular Research Laboratory (J.M.), Instituto de Biomedicina de Sevilla-IbiS; Rio Hortega University Hospital (M.A.T.A.), University of Valladolid; Cerebrovascular Diseases (A.R.V.), Hospital Clinic of Barcelona, Spain; Department of Neurology (M. Mazya), Karolinska University Hospital and Department of Clinical Neuroscience, Karolinska Institute, Stockholm, Sweden; Department of Interventional Neuroradiology (G.B.), University Hospitals of Geneva; Department of Interventional and Diagnostic Neuroradiology (A.B., M.-N.P.), Radiology and Nuclea Medicine, University Hospital Basel; Department of Neurology (U.F.), University of Bern; Department of Neuroradiology (J.G.), University of Bern; Department of Neuroscience (P.L.M., D.S.), Lausanne University Hospital, Switzerland; Department of Stroke Medicine (S.B., J. Kwan), Imperial College Healthcare NHS Trust, Charing Cross Hospital, London; Department of Neurology (K.K.), Queen's Medical Centre, Nottingham University Hospitals NHS Trust, United Kingdom; Department of Neurology (A.B., A Shuaib), University of Alberta, Edmonton; Department of Neurology (L.C., A. Shoamanesh), McMaster University, Hamilton; Department of Clinical Neurosciences and Hotchkiss Brain Institute (A.M.D. M.D.H.), University of Calgary; Department of Neurology (T.F., S.Y.), University of British Columbia, Vancouver; Mackenzie Health (J.H., C.A.S.) Richmond Hill, Ontario; Department of Neurology (H.K.) Sunnybrook Health Sciences Centre, University of Toronto; Department of Neurology (A. Mackey), Hopital Enfant Jesus, Centre Hospitalier de l'Universite Laval, Quebec City; Department of Neurology (A.P.), University of Toronto; Medicine (G.S.), St. Michael's Hospital, University of Toronto, Canada Department of Neurosciences (M.A.B.), Hospital Dr. Rafael A. Calderon Guardia, CCSS. San Jose, Costa Rica; Neurovascular Service (J.D.B.), Hospital General San Juan de Dios, Guatemala City; Department of Neurología (L.I.P.R.), Hospital General de Enfermedades, Instituto Guatemalteco de Seguridad Social, Guatemala City, Guatemala; Department of Neurology (F.G.-R.), University Hospital Jose Eleuterio Gonzalez, Universidad Autonoma de Nuevo Leon, Mexico; Pacifica Salud-Hospital Punta Pacífica (N.N.-E. A.B., R.K.), Panama; Department of Neurology, Radiology (M.A.), University of Kansas Medical Center Department of Neurointerventional Neurosurgery (D. Altschul), The Valley Baptist Hospital, Ridgewood, New Jersey; Palmetto General Hospital (A.J.A.-O.), Tenet, Florida; Neurology (I.B., P.K.), University Hospital Newark, New Jersey Medical School, Rutgers, Newark, New Jersey; Community Healthcare System (A.B.), Munster, Indiana; Department of Neurology (N.B., C.B.N.), California Pacific Medical Center, San Francisco; Department of Neurology (C.B.), Mount Sinai South Nassau, New York; University of Toledo (A.C.), Ohio; Department of Neurology (S.C.), University of Maryland School of Medicine, Baltimore, Maryland; Neuroscience (S.A.C.), Inova Fairfax Hospital, Virginia; Department of Neurology (H.C.), Abington Jefferson Hospital, Pennsylvania; Department of Neurology (J.H.C.), Mount Sinai South Nassau, New York; Baptist Health Medical Center (S.D.), Little Rock, Arkansas; Department of Neurology (K.D.), HCA Houston Healthcare Clearlake, Texas; Department of Neurology (T.G.D., R.S.), Erlanger, Tennessee; Wilmington North Carolina (V.T.D.); Department of Vascular and Neurointerventional Ser vices (R.E.), St. Louis University, Missouri; Department of Neurology (M.E.), Massachusetts General Hospital, Boston; Department of Neurology, Neurosurgery, and Radiology (M.F., S.O.-G., N.R.), University of Iowa Hospitals and Clinics, Iowa City; Department of Radiology (D.F.), Swedish Medical Center, Englewood, Colorado; Department of Radiology (D.G.), Neurosurgery, University of Maryland School of Medicine, Baltimore, Maryland; Adventist Health Glendale Comprehensive Stroke Center (M.G.), Los Angeles, California; Wellstar Neuroscience Institute (R.G.), Marietta, Georgia; Department of Neurology (A.E.H.), University of Texas Rio Grande Valley-Valley Baptist Medical Center, Texas; Department of Neurology (J.H., B.V.), Lahey Hospital \& Medical Center, Beth Israel Lahey Health, Burlington, Massachusetts; Department of Neurology (A.M.K.), Wayne State, Detroit, Michigan; HSHS St. John's Hospital (N.N.K.), Southern Illinois University School of Medicine, Springfield; Virginia Hospital Center (B.S.K.) Arlington; Department of Neurology, University of Michigan, Ann Arbor; Weill-Cornell Medical College (D.O.K.), New York-Presbyterian Queens; Department of Neurology (V.H.L.), Ohio State University, Columbus; Department of Neurology (L.Y.L.), Tufts Medical Center, Boston, Massachusetts; Vascular and Neurointerventional Services (G.L.), St. Louis University, Missouri; Miami Cardiac \& Vascular Institute (I.L., A.K.S.), Florida; Department of Neurology (H.L.L.), Oregon Health \& Science University, Portland Department of Emergency Medicine (L.M., M.S.), Steward Holy Family Hospital, Methuen, MA; Vidant Medical Center (S.M.), Greenville, North Carolina; Department of Neurology (A.M.M., D.R.Y.) and Neurosurgery (D.R.Y.), University of Miami Miller School of Medicine, Florida; Department of Neurology (H.M.), SUNY Upstate New York, Syracuse; Memorial Neuroscience Institute (B.P.M.), Pembroke Pines, Florida; Neurosciences (J.M., J.P.T.), Spectrum Health, Michigan State University College of Medicine, Grand Rapids, Michigan; Sutter Health (M.M.), Sacramento, California; Department of Neurology (J.G.M.), Maine Medical Center, Portland; Department of Neurology (S.S.M.), Bayhealth, Dover, Delaware; Department of Neurology and Pediatrics (F.N.), Emory University, Atlanta, Georgia; Department of Neurology (K.N.), University of Arkansas for Medical Sciences, Little Rock; Department of Radiology and Neurology (R.N.-W.), UT Southwestern Medical Center, Dallas, Texas; Ascension St. John Medical Cente (R.H.R.), Tulsa, Oklahoma; Riverside Regional Medical Center (P.R.), Newport, Virginia; Department of Neurology (J.R.R., T.N.N.), Boston University School of Medicine, MA; Department of Neurology (A.R.), Hospital of the University of Pennsylvania, Philadelphia; Department of Neurology (M.S.), University of Washington School Medicine, Seattle; Department of Neurology (B.S.), University of Massachusetts Medical Center, Worcester; Department of Neurology (A.S.), CHI-Immanuel Neurological Institute, Creighton University, Omaha, Nebraska; Holy Cross Hospital (S.L.S.), Fort Lauderdale, Florida; Department of Neurology (V.S.), Interventional Neuroradiology, University of California in Los Angeles Banner Desert Medical Center (M.T.), Mesa, Arizona; Hospital de Agudos Dr. Ignacio Privano (O.B., A.L.) Argentina; Institute for Neurological Research, FLENI (V.A.P.L.), Buenos Aires, Argentina; Hospital da Clinicas/São Paulo University (M.S.A., A.C.); Sumare State Hospital (F.B.C., L.V.), São Paulo; Hospital Vera Cruz (L.D.D.S.), Deus Campinas; Irmanandade Santa Casa de Porto Alegre (L.V.G.); Stroke Unit (F.O.L., F. Mont'alverne), Hospital Geral de Fortaleza; Stroke Unit (A.L.L., P.S.C.M.), Hospital Sao Jose, Joinville, Santa Catarina; Stroke Unit (R.T.M.), Neurology, Nossa Senhora da Conceição Hospital, Porto Alegre; Department of Neurology (D.L.M.C.), Hospital Moinhos de Vento, Porto Alegre; Department of Neurology (L.C.R.), Hospital de Base do Distrito Federal; Hospital Ana (V.F.C.), Hospital Juliane, Federal University of Parana, Curitiba, Brazil; Vascular Neurology Unit (P.M.L., V.V.O.), Neurology Service, Department of Neurology and Psychiatry, Clínica Alemana, Universidad del Desarrollo, Santiago; Hospital Padre Hurtado (V.N., J.M.A.T.) Santiago, Chile; Fundación Valle del Lili (P.F.R.A.), Cali; Stroke Center (H.B.), Fundación Santa Fe de Bogotá; Department of Neurology (A.B.C.-Q.), Hospital Departamental Universitario del Quindio San Juan de Dios, Armenia; Clinica Universitaria Colombia (C.E.R.O.), Bogotá University Hospital of San Vicente Foundation (D.K.M.B.), Medellin; Barranquilla, Colombia (O.L.) Hospital Infantil Universitario de San Jose (M.R.P.), Bogota; Stroke Unit (L.F.D.-E.), Hospital de Clínicas, Facultad de Ciencias Médicas, Universidad Nacional de Asunción; Neurology Service (D.E.D.M.F., A.C.V.),
Hospital Central del Instituto de Prevision Social, Paraguay; Internal Medicine Service (A.J.Z.Z.), Hospital Central de Policia "Rigoberto Caballero", Paraguay; National Institute of Neurological Sciences of Lima Peru (D.M.B.I.); Hospital Edgardo Rebagliati Martins Lima-Peru (L.R.K.); Department of Neurology (B.C.), Royal Melbourne Hospital; Department of Neurology (G.J.H.), Sir Charles Gairdner Hospital and Medical School, Faculty of Health and Medical Sciences, The University of Western Australia, Perth; University of Melbourne (C.H., R.S.), Ballarat Health Service, Australia University of Melbourne; Department of Neurolog (T.K.), Royal Adelaide Hospital; Department of Neurosurgery (A. Ma), Royal North Shore Hospital, Sydney Department of Neurology (R.T.M.), Mater Hospital, Brisbane; Department of Neurology (R.S.), Austin Health, Victoria; Florey Institute of Neuroscience and Mental Health (R.S.), Parkville, Melbourne, Australia; Greymouth Base Hospital (D.S.), New Zealand; Department of Neurology (T.Y.H.W.), Christchurch Hospital, New Zealand; Department of Neurology (D.L.), University of California in Los Angeles; and Department of Neurology (O.O.Z.), Mercy Health Neurosciences, Toledo, Ohio

\section{Study Funding}

The authors report no targeted funding.

\section{Disclosure}

Dr. Nogueira reports consulting fees for advisory roles with Anaconda, Biogen, Cerenovus, Genentech, Imperative Care, Medtronic, Phenox, Prolong Pharmaceuticals, Stryker Neurovascular and stock options for advisory roles with Astrocyte, Brainomix, Cerebrotech, Ceretrieve, Corindus Vascular Robotics, Vesalio, Viz-AI, and Perfuze. Dr. Martins reports receiving lecture fees from Bayer, Medtronic, Penumbra and speaker / advisory board fees from Boehringer Ingelheim. Dr. Czlonkowska reports service as Expert Witness. Dr. Siegler served as a consultant for Ceribell and the institution of Dr. Siegler has received research support from the National Institutes of Health. The institution of Dr. Czap has received research support from the National Institutes of Health. Dr. Holmstedt served as a consultant for Astrazeneca and the institution of Dr. Holmstedt has received research support from the National Institutes of Health, the Patient-Centered Outcomes Research Institute, and CSPC Pharmaceuticals. Dr. Holmstedt served as a Study Adjudicator with Ischemia Care. Dr. Turan served on a scientific advisory or DSMB for Pfizer/Merck and Gore Inc. and has received publishing royalties from a publication relating to health care. Dr. Alexandrov served on a speakers bureau for Genentech and the institution of Dr. Alexandrov has received research support from the National Institutes of Health. Dr. Huang served on a scientific advisory or DSMB for ReNeuron and KMPHC. Dr. Raz served as an expert witness for law firms and has received publishing royalties from a publication relating to health care. Dr. Sheth served as a consultant for Penumbra and Cerenovus. The institution of Dr. Frankel has received research support from Nico Corporation, Inc. Dr. Rahman served as a consultant for the Ministry of Health and family Planning, Bangladesh, has received research support from the Ministry of Science and Technology, Bangladesh, and has received publishing royalties from a publication relating to health care. The institution of Dr. Sylaja has received research support from Sree Chitra Tirunal Institute for Medical Sciences and Technology. Dr. Farhoudi served as an officer or member of the board of directors for Kenes. Dr. Hokmabadi served on a speakers bureau for ArvandPharmed and Osve Pharmaceutical Company. The institution of Dr. Sakai has received research support from DaiichiSankyo and Terumo. Dr. Sakai has served as a lecture honoralium with Asahi Intec. Dr. Yagita served on a scientific advisory or DSMB for Shionogi, has served on a speakers bureau for Daiichi-Sankyo, Eisai, Bristol- 
Myers Squibb, Abbvie, Astellas, Pfizer, Otsuka, Sumitomo Dainippon, Mitsubishi Tanabe, Kowa, Bayer, and Kyowa Kikaku. The institution of Dr. Yagita has received research support from Takeda. Dr. Matsumaru served on a speakers bureau for Medtronic, Stryker, Terumo, J\&J, and Kaneka. The institution of Dr. Todo has received research support from JSPS KAKENHI Grant Number 20K07885. Dr. Todo has served as a lecturer with Medtronic, Bristol-Myers Squibb, Pfyzer, Byer, Daiichi Sankyo, and Stryker. The institution of Dr. Sonoda has received research support from The Ministry of Education, Culture, Sports, Science and Technology, Japan. Dr. Zaidi served as a consultant for Boehringer Ingelheim and Medtronic and The institution of Dr. Zaidi has received research support from The George Institute and The Florey Institute of Neuroscience and Mental Health. Dr. Al-Jehani served as an editor, associate editor, or editorial advisory board member for Boerhinger Ingelheim. Dr. Chen has received research support from the Ministry of Science and Technology. The institution of Dr. Gattringer has received research support from the Austrian Neurological Society. Dr. Killer-Oberpfalzer served as a consultant for Medtronic and Microvention. Dr. Vanhooren served as a consultant for BAYER. Dr. Pierre Rutgers served on a scientific advisory or DSMB for Novartis, Daiichi Sankyo, Bayer, Boehringer Ingelheim, and Piramal Imaging Limited. Dr. Budincevic served on a scientific advisory or DSMB for Boehringer Ingelheim, served on a speakers bureau for Bayer, and The institution of Dr. Budincevic has received research support from Novo Nordisk. Dr. Klecka served as a consultant for Novartis and served on a scientific advisory or DSMB for Novartis and Teva. The institution of Dr. Hlinovsky has received research support from AstraZeneca. Dr. Klingenberg Iversen served on a scientific advisory or DSMB for BAYER and Boehringer Ingelheim, has served as an officer or member of the board of directors for the Danish Stroke Society, and has received publishing royalties from a publication relating to health care. The institution of Dr. Simonsen has received research support from Novo Nordisk Foundation. Dr. GrossPaju served on a scientific advisory or DSMB for Sanofi Genzyme and Novartis, and has served on a speakers bureau for Merck. Dr. Cordonnier served on a scientific advisory or DSMB for Biogen (steering committee) and BMS (steering committee), has served on a speakers bureau for BoehringerIngelheim, and as an editor, associate editor, or editorial advisory board member for Stroke journal. The institution of Dr. Cordonnier has received research support from the French ministry of health. Dr. Eker served as a consultant for Cerenovus. Dr. Ondze served as a consultant for Novartis. Dr. Fernando Pico served on a speakers bureau for Boehringer. Dr. Krishnan has served on the speakers bureau for Daiichi Sankyo. Dr. Nagel served as a consultant for Brainomix, and has served on a speakers bureau for Böhringer Ingelheim and BMS Pfizer. Dr. Ringleb served on a scientific advisory or DSMB for Boehringer Ingelheim, and has served on a speakers bureau for Boehringer Ingelheim, Bayer, Daiichi Sankyo, and Pfizer. The institution of Dr. Schmidt has received research support from Biomerieux and GBA, German
Federal Government. Dr. Schmidt has received intellectual property interests from a discovery or technology relating to health care and served as an examiner with Board of Physicians Lower Saxony. The institution of Dr. Siepmann has received research support from the German Federal Ministry of Health. Dr. Siepmann has received publishing royalties from a publication relating to health care. Dr. Szabo has received research support from Ministry of Science and Research, Baden-Württemberg, Germany. Dr. Szabo has received publishing royalties from a publication relating to health care. Dr. Thomalla served as a consultant for Acandis, Strykern, and Portolam, and served on a speakers bureau for Daiichi Sankyo and Bristol Myers Squibb / Pfizer. Dr. Klivenyi served as a consultant for Biogen and Abbvie. Dr. Karlinski, served as a consultant for Boehringer Ingelheimm, served on a scientific advisory or DSMB for Boehringer Ingelheim, Bayer, Medtronic, and Boehringer Ingelheim, and has served on a speakers bureau for Bayer and Medtronic. Dr. Sienkiewicz-Jarosz served on a speakers bureau for Servier and Medical Tribune. The institution of Dr. Sienkiewicz-Jarosz received research support from The National Centre for Research and Development. Dr. Fryze served as a consultant for Roche, Merck, and Biogen, served on a speakers bureau for Roche, Merck, and Novartis and has received research support from Roche, Merck, Biogen, Alkermes, AstraZeneca, Bayer, and Actelion. Dr. Arenillas has served as a consultant for Bayer, Boehringer Ingelheim, Daiichi-Sankyo, Amgen, and Pfizer, served on a scientific advisory or DSMB for AstraZeneca, Amgen, Fundació Ictus Barcelona, and served on a speakers bureau for Daiichi-Sankyo, Bayer, and Boehringer. The institution of Dr. Arenillas has received research support from Carlos III Health Institute, Madrid, Spain, the European Union-European Commission, and the Department of Education, Castilla y Leon Regional GVNT. Dr. Ayo Martin served as an expert witness for Daiichi-Sankyo and the institution of Dr. Ayo Martin has received research support from Daiichi-Sankyo and the Spanish Society of Neurosonology. The institution of Dr. Montaner has received research support from the Spanish government and has received intellectual property interests from a discovery or technology relating to health care. The institution of Dr. Fischer has received research support from Medtronic. The institution of Dr. Gralla has received research support from Medtronic. Dr. Michel has served as a consultant for Medtronic, served on a scientific advisory or data safety monitoring board for Penumbra, and has received research support from the Swiss National Science Foundation; Swiss Heart Foundation. Dr. Strambo has received research support from University of Lausanne and the institution of Dr. Strambo has received research support from Swiss Heart Foundation. Dr. Catanese served as a consultant for IschemiaCare. Dr. Demchuk served as a consultant for Medtronic, served on a scientific advisory or data safety monitoring board for Lumosa, and served on a speakers bureau for Pfizer/BMS and Boehringer Ingelheim. Dr. Demchuk has received stock or an ownership interest from Circle NVI and has received intellectual property interests from a discovery or technology relating to health care. 
Dr. Field has received personal compensation for serving as an employee of Springer. Dr. Field served as an expert witness for the Canadian Medical Protective Association. The institution of Dr. Field has received research support from Bayer Canada. Dr. Hill served as a consultant for Boehringer Ingelheim, served on a scientific advisory or data safety monitoring board for Sun Pharma, and has received stock or an ownership interest from Circle Neurovascular. Dr. Saposnik served as a consultant for Roche, Celgene, and Servier, and served on a scientific advisory or data safety monitoring board for the NIHSS. The institution of Dr. Saposnik has received research support from Roche and the Heart and Stroke Foundation of Canada. Dr. Shoamanesh served on a scientific advisory or data safety monitoring board for Bayer AG and Daiichi Sankyo and has served on a speakers bureau for Servier Inc. Dr. Shoamanesh served as an editor, associate editor, or editorial advisory board member for Neurodiem.ca. The institution of Dr. Shoamanesh has received research support from Servier Canada Inc., Daiichi Sankyo Ltd., Bayer AG, Bristol-Myers Squibb, and Octapharma Canada. Dr. Abraham served as a consultant for Stryker Neurovascular. An immediate family member of Dr. Altschul has received personal compensation in the range of $\$ 50,000-\$ 99,999$ for serving as a consultant for Microvention and Stryker. The institution of Dr. Altschul has received research support from Max Kade. Dr. Badruddin has received intellectual property interests from a discovery or technology relating to health care. Dr. Chaturvedi served as an editor, associate editor, or editorial advisory board member for the American Heart Association. Dr. Chaturvedi served as an expert witness for Various and the institution of Dr. Chaturvedi has received research support from NINDS. Dr. Choi has received intellectual property interests from a discovery or technology relating to health care. Dr. Devlin served as a consultant for Neural Analytics, Viz.ai, and Medtronic, has served on a speakers bureau for Medtronic, Viz.ai, and served as an officer or member of the board of directors for Neuroscience Innovation Foundation. Dr. Devlin has received stock or an ownership interest from Neural Analytics and Viz.ai. The institution of Dr. Devlin has received research support from Viz.ai. Dr. Devlin has received research support from Neural Analytics. Dr. Etherton served as a consultant for WorldCare Clinical and has received research support from the American Academy of Neurology. Dr. Etherton has received research support from MGH Executive Council on Research and received publishing royalties from a publication relating to health care. Dr. Frei served as a consultant for Philips, Stryker, and Siemens, has served on a scientific advisory or data safety monitoring board for Shape Memory Medical and has served on a speakers bureau for Genentech, Stryker, Penumbra, and Viz.ai. Dr. Frei has received stock or an ownership interest from Penumbra, and has received research support from Penumbra. Dr. Ameer Hassan served as a consultant for Medtronic, Stryker, Penumbra, Cerenovus, and Viz.ai. Dr. Hassan served on a speakers bureau for Genentech and has received research support from GE Healthcare. Dr. Leung has received research support from NIH. Dr. Linfante has received personal compensation for serving as an employee of Medtronic, Stryker, Cerenovus. Dr. Linfante has received personal compensation in the range of $\$ 100,000-\$ 499,999$ for serving as a consultant for Medtronic, and has received stock or an ownership interest from InNeuroCO and Stryker/Surpass. Dr. Lutsep served as a consultant for Abbott and served on a scientific advisory or data safety monitoring board for BMS, Coherex Medical, and NINDS/Mayo Cinic. Dr. Lutsep served as an editor, associate editor, or editorial advisory board member for Medscape Neurology. Dr. McDermott has served as an editor, associate editor, or editorial advisory board member for the American College of Cardiology, served as an expert reviewer with Michigan LARA, and has a noncompensated relationship as a consultant with Mitovation that is relevant to AAN interests or activities. Dr. Nahab served as an expert witness for legal consultation and has received intellectual property interests from a discovery or technology relating to health care. Dr. Ortega Gutierrez served as a consultant for Stryker and Medtronic and served as an officer or member of the board of directors for SVIN. The institution of Dr. Ortega Gutierrez received research support from Stryker. Dr. Ramakrishnan served as a symposium honorarium with Cerenovus. The institution of Dr. Romero has received research support from the NIH/NIA. Dr. Rost served on a scientific advisory or data safety monitoring board for Omiox and Abbvie, and served as an editor, associate editor, or editorial advisory board member for Stroke-AHA/ASA Journal. The institution of Dr. Rost has received research support from the NIH. Dr. Rost has received intellectual property interests from a publication relating to health care and served as an instructor with the Heart and Rhythm Society. Dr. Ruland served as an editor, associate editor, or editorial advisory board member for Up to Date and served as an expert witness for law firms. Dr. Silver served as an expert witness for various legal firms, has received intellectual property interests from a discovery or technology relating to health care, has received publishing royalties from a publication relating to health care, and served as a consultant with Women's Health Initiative and Best Doctors, Inc. Dr. Silver has a noncompensated relationship as a consultant with ABPN that is relevant to AAN interests or activities. Dr. Silver has a noncompensated relationship as a member of the regional board of directors with the American Heart Association that is relevant to AAN interests or activities. Dr. Szeder served as a consultant for Medtronic and as an expert witness for Carroll, Kelly, Trotter, Franzen, McBride \& Peabody LLP. Dr. Szeder served as an expert witness for Peabody and Buccini LLP. Dr. Tsai served as a consultant for Cerenovus. Dr. Conforto has received research support from the NIH, FAPESP, CNPq, and MIT, served as an author with Springer, and served as a speaker with Manole and EEP-USP. Fabricio Oliveira Lima served on a speakers bureau for Boehringer Ingelheim. Dr. Lavados served on a scientific advisory or data safety monitoring board for Boehringer Ingelheim and served on a speakers bureau for Boehringer Ingelheim. Dr. Lavados has received research support from ANID-FONDECYT. Dr. Hankey served as a consultant for Bayer, served on a scientific advisory or data safety monitoring board for AC Immune, and served as an editor, associate editor, or editorial advisory board member for the American Heart Association. Dr. Thijs served as a 
consultant for Medtronic, Allergan, BMS, and served on a speakers bureau for Pfizer and Boehringer Ingelheim. Dr. Haussen served as a consultant for Stryker and received stock or an ownership interest from Viz.ai. Dr. Liebeskind has received research support from Cerenovus, Genentech, Medtronic, and Stryker. Dr. Yavagal served as a consultant for Johnson \& Johnson, Neural Analytics, Inc., Rapid Medical Ltd., and Guidepoint Global, has served on a scientific advisory or data safety monitoring board for Neural Analytics, Inc., Carnival Cruises, Medtronic, Royal Carribean Cruises Ltd., and Guidepoint Global, has served on a speakers bureau for Medtronic, and served as an editor, associate editor, or editorial advisory board member for Goldberg Segalla LLP. Dr. Yavagal served as an expert witness for Rourke and Blumenthal, LLP, Eadie Hill Trial Lawyers, and Goldberg Segalla LLP. Dr. Jovin served as a consultant for Cerenovus, served on a scientific advisory or data safety monitoring board for Contego Medical, served as an expert witness for several law firms, and. has received stock or an ownership interest from Corindus, Methinks, and Viz.ai. The institution of Dr. Jovin has received research support from Stryker and Medtronic. The institution of Dr. Nguyen received research support from Medtronic and SVIN. The remaining authors report no disclosures relevant to the manuscript. Go to Neurology.org/N for full disclosures.

\section{Publication History}

Received by Neurology October 30, 2020. Accepted in final form March 11, 2021.

\section{Appendix 1 Authors}

$\overline{\text { Authors, their locations, and their contributions are listed at links.Iww.com/ }}$ WNL/B357

Appendix 2 Coinvestigators

\begin{tabular}{llll}
\hline Name & Location & Role & Contribution \\
\hline $\begin{array}{l}\text { Judith Clark, } \\
\text { RN }\end{array}$ & Boston Medical Center & Collaborator & $\begin{array}{l}\text { Contribution } \\
\text { of data }\end{array}$ \\
\hline $\begin{array}{l}\text { Cheryl } \\
\text { Grant, RN }\end{array}$ & $\begin{array}{l}\text { Neurology, Medical } \\
\text { University of South } \\
\text { Carolina, Charleston }\end{array}$ & Collaborator & $\begin{array}{l}\text { Contribution } \\
\text { of data }\end{array}$ \\
\hline $\begin{array}{l}\text { Mazlina } \\
\text { Husin, } \\
\text { MMed }\end{array}$ & $\begin{array}{l}\text { Hospital Sultanah Nur } \\
\text { Zahirah Kuala }\end{array}$ & Collaborator & $\begin{array}{l}\text { Contribution } \\
\text { of data }\end{array}$ \\
\hline $\begin{array}{l}\text { Crivorucica } \\
\text { Igor, MD }\end{array}$ & $\begin{array}{l}\text { Emergency Medicine } \\
\text { Institute, Chisinau, } \\
\text { Republic of Moldova }\end{array}$ & Collaborator & $\begin{array}{l}\text { Contribution } \\
\text { of data }\end{array}$ \\
\hline $\begin{array}{l}\text { Steve } \\
\text { Withington, } \\
\text { MD, FRACP }\end{array}$ & $\begin{array}{l}\text { Ashburton Hospital, } \\
\text { Ashburton, New }\end{array}$ & Collaborator & $\begin{array}{l}\text { Contribution } \\
\text { Zeal data }\end{array}$ \\
\hline $\begin{array}{l}\text { Mandy Lau, } \\
\text { MD }\end{array}$ & $\begin{array}{l}\text { University of } \\
\text { Melbourne, Ballarat }\end{array}$ & Collaborator & $\begin{array}{l}\text { Contribution } \\
\text { of data }\end{array}$ \\
& $\begin{array}{l}\text { Health Service, } \\
\text { Australia }\end{array}$ & & \\
\hline
\end{tabular}

Appendix 2 (continued)

\begin{tabular}{llll}
\hline Name & Location & Role & Contribution \\
\hline $\begin{array}{l}\text { Thomas } \\
\text { Kraemer, }\end{array}$ & $\begin{array}{l}\text { University of } \\
\text { Melbourne, Ballarat }\end{array}$ & Collaborator & $\begin{array}{l}\text { Contribution } \\
\text { of data }\end{array}$ \\
& $\begin{array}{l}\text { Health Service, } \\
\text { Australia }\end{array}$ & & \\
\hline
\end{tabular}

\section{References}

1. Emanuel EJ, Persad G, Upshur R, et al. Fair allocation of scarce medical resources in the time of covid-19. N Engl J Med 2020;382:2049-2055.

2. Elkind MSV, Boehme AK, Smith CJ, Meisel A, Buckwalter MS. Infection as a stroke risk factor and determinant of outcome after stroke. Stroke 2020;51:3156-3168.

3. Yaghi S, Ishida K, Torres J, et al. SARS-CoV-2 and stroke in a New York healthcare system. Stroke 2020;51(7):2002-2011.

4. Siegler JE, Cardona P, Arenillas JF, et al. Cerebrovascular events and outcomes in hospitalized patients with COVID-19: the SVIN COVID-19 Multinational Registry. Int J Stroke Epub 2020 Sep 30.

5. Hernández-Fernández F, Valencia HS, Barbella-Aponte RA, et al. Cerebrovascular disease in patients with COVID-19: neuroimaging, histological and clinical description. Brain 2020;143(10):3089-3103.

6. Ntaios G, Michel P, Georgiopoulos G, et al. Characteristics and outcomes in patients with COVID-19 and acute ischemic stroke: the global COVID-19 stroke registry. Stroke 2020;51(9):e254-e258.

7. Tsivgoulis G, Katsanos AH, Ornello R, Sacco S. Ischemic stroke epidemiology during the COVID-19 pandemic: navigating uncharted waters with changing tides. Stroke 2020;51(7):1924-1926.

8. Ma A, Kase CS, Shoamanesh A, et al. Stroke and thromboprophylaxis in the era of COVID-19. J Stroke Cerebrovasc Dis 2020;30(1):105392.

9. Huang JF, Greenway MRF, Nasr DM, et al. Telestroke in the time of COVID-19: the mayo clinic experience. Mayo Clin Proc 2020;95(8):1704-1708.

10. Rudilosso S, Laredo C, Vera V, et al. Acute stroke care is at risk in the era of COVID-19: experience at a comprehensive stroke center in Barcelona. Stroke 2020;51(7):1991-1995.

11. Zhao J, Li H, Kung D, Fisher M, Shen Y, Liu R. Impact of the COVID-19 epidemic on stroke care and potential solutions. Stroke 2020;51(7):1996-2001.

12. Kerleroux B, Fabacher T, Bricout N, et al. Mechanical thrombectomy for acute ischemic stroke amid the COVID-19 outbreak: decreased activity, and increased care delays. Stroke 2020;51(7):2012-2017.

13. Kristoffersen ES, Jahr SH, Thommessen B, Rønning OM. Effect of COVID-19 pandemic on stroke admission rates in a Norwegian population. Acta Neurol Scand 2020;142(6):632-636.

14. Han MH, Yi HJ, Kim YS, Kim YS. Effect of seasonal and monthly variation in weather and air pollution factors on stroke incidence in Seoul, Korea. Stroke 2015;46(4):927-935.

15. Sacco S, Ricci S, Ornello R, et al. Reduced admissions for cerebrovascular events during COVID-19 outbreak in Italy. Stroke 2020;51(12):3746-3750.

16. Pop R, Quenardelle V, Hasiu A, et al. Impact of the COVID-19 outbreak on acute stroke pathways: insights from the Alsace region in France. Eur J Neurol 2020;27(9):1783-1787.

17. Hoyer C, Ebert A, Huttner HB, et al. Acute stroke in times of the COVID-19 pandemic: a multicenter study. Stroke 2020;51(7):2224-2227.

18. Diegoli H, Magalhães PSC, Martins SCO, et al. Decrease in hospital admissions for transient ischemic attack, mild, and moderate stroke during the COVID-19 era. Stroke 2020;51(8):2315-2321.

19. Katsanos AH, de Sa Boasquevisque D, Al-Qarni MA, et al. In-hospital delays for acute stroke treatment delivery during the COVID-19 pandemic. Can J Neurol Sci 2020:1-7.

20. Siegler JE, Heslin ME, Thau L, Smith A, Jovin TG. Falling stroke rates during COVID-19 pandemic at a comprehensive stroke center. J Stroke Cerebrovasc Dis 2020;29(8):104953.

21. Hsiao J, Sayles E, Antzoulatos E, et al. Effect of COVID-19 on emergent stroke care: a regional experience. Stroke 2020;51(9):e2111-e2114.

22. Uchino K, Kolikonda MK, Brown D, et al. Decline in stroke presentations during COVID-19 surge. Stroke 2020;51(8):2544-2547.

23. Nogueira RG, Abdalkader M, Qureshi M, et al. Global impact of the COVID-19 pandemic on stroke hospitalizations and mechanical thrombectomy volumes. Int $\mathrm{J}$ Stroke Epub 2021 Jan 18.

24. Nguyen TN, Haussen DC, Qureshi M, et al. Decline in subarachnoid hemorrhage volumes associated with the first wave of the COVID-19 pandemic. Stroke Vasc Neurol Epub 2021 Mar 26.

25. American Heart Association's Mission: Lifeline and Get With the Guidelines Coronary Artery Disease Advisory Work Group and the Council on Clinical Cardiology's Committees on Acute Cardiac Care and General Cardiology and Interventional Cardiovascular Care. Temporary emergency guidance to STEMI systems of care during the COVID-19 pandemic: AHA's mission: lifeline. Circulation 2020;142(3):199-202.

26. Nguyen TN, Abdalkader M, Jovin TG, et al. Mechanical thrombectomy in the era of the COVID-19 pandemic: emergency preparedness for neuroscience teams: a guidance statement from the Society of Vascular and Interventional Neurology. Stroke 2020;51(6):1896-1901.

27. Nguyen TN, Jadhav AP, Dasenbrock HH, et al. Subarachnoid hemorrhage guidance in the era of the COVID-19 pandemic: an opinion to mitigate exposure and conserve personal protective equipment. J Stroke Cerebrovasc Dis 2020; 29(9): 105010 . 


\section{Neurology}

Global Impact of COVID-19 on Stroke Care and IV Thrombolysis

Raul G. Nogueira, Muhammad M. Qureshi, Mohamad Abdalkader, et al. Neurology 2021;96; e2824-e2838 Published Online before print March 25, 2021

DOI 10.1212/WNL.0000000000011885

\section{This information is current as of March 25, 2021}

\section{Updated Information \& Services}

References

Citations

Subspecialty Collections

Permissions \& Licensing

\section{Reprints}

including high resolution figures, can be found at: http://n.neurology.org/content/96/23/e2824.full

This article cites 23 articles, 1 of which you can access for free at: http://n.neurology.org/content/96/23/e2824.full\#ref-list-1

This article has been cited by 4 HighWire-hosted articles: http://n.neurology.org/content/96/23/e2824.full\#\#otherarticles

This article, along with others on similar topics, appears in the following collection(s):

All Cerebrovascular disease/Stroke

http://n.neurology.org/cgi/collection/all_cerebrovascular_disease_strok e

\section{COVID-19}

http://n.neurology.org/cgi/collection/covid_19

Information about reproducing this article in parts (figures,tables) or in its entirety can be found online at:

http://www.neurology.org/about/about_the_journal\#permissions

Information about ordering reprints can be found online:

http://n.neurology.org/subscribers/advertise

Neurology ${ }^{\circledR}$ is the official journal of the American Academy of Neurology. Published continuously since 1951, it is now a weekly with 48 issues per year. Copyright () 2021 American Academy of Neurology. All rights reserved. Print ISSN: 0028-3878. Online ISSN: 1526-632X.

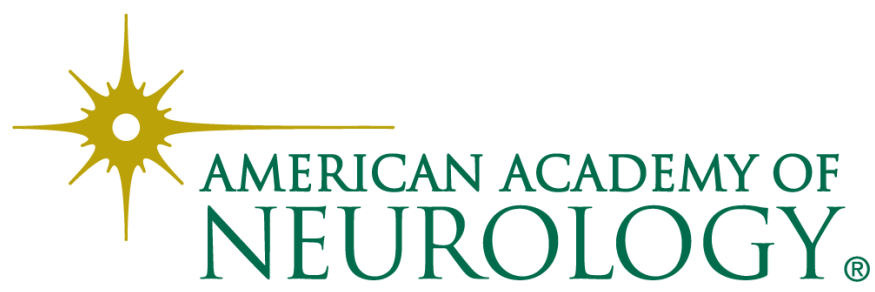

